\title{
T Cell/B Cell Interactions in the Establishment of Protective Immunity
}

\author{
Julia Ritzau-Jost and Andreas Hutloff * \\ Institute of Immunology, University Hospital Schleswig-Holstein, 24105 Kiel, Germany; \\ julia.ritzaujost@gmail.com \\ * Correspondence: andreas.hutloff@uksh.de
}

Citation: Ritzau-Jost, J.; Hutloff, A. $\mathrm{T}$ Cell/B Cell Interactions in the Establishment of Protective Immunity. Vaccines 2021, 9, 1074. https:// doi.org/10.3390/vaccines9101074

Academic Editors: Dirk Mielenz and Anja Erika Hauser

Received: 31 August 2021

Accepted: 20 September 2021

Published: 24 September 2021

Publisher's Note: MDPI stays neutral with regard to jurisdictional claims in published maps and institutional affiliations.

Copyright: (c) 2021 by the authors. Licensee MDPI, Basel, Switzerland. This article is an open access article distributed under the terms and conditions of the Creative Commons Attribution (CC BY) license (https:// creativecommons.org/licenses/by/ $4.0 /)$.

\begin{abstract}
Follicular helper T cells (Tfh) are the T cell subset providing help to B cells for the generation of high-affinity antibodies and are therefore of key interest for the development of vaccination strategies against infectious diseases. In this review, we will discuss how the generation of Tfh cells and their interaction with B cells in secondary lymphoid organs can be optimized for therapeutic purposes. We will summarize different $\mathrm{T}$ cell subsets including Tfh-like peripheral helper $\mathrm{T}$ cells (Tph) capable of providing B cell help. In particular, we will highlight the novel concept of T cell/B cell interaction in non-lymphoid tissues as an important element for the generation of protective antibodies directly at the site of pathogen invasion.
\end{abstract}

Keywords: follicular helper T cells; peripheral helper T cells; germinal center reaction; vaccination; inflamed tissues; cytokines

\section{Introduction}

Vaccination strategies against infectious diseases are typically based on the generation of long-lived high-affinity antibodies, which are capable of combating pathogens in multiple mechanisms. This includes neutralization of toxins or prevention of receptor-specific virus entry into host cells. Moreover, antibody opsonization of pathogens constructively promotes their destruction mediated by the complement system or phagocytosis [1]. Despite the immense success of vaccinations, which has effectively eliminated or vastly reduced a wide range of formerly devastating infections, there still remains a wide range of communicable diseases for which efficient vaccination strategies are in order. Furthermore, many of the existing vaccine regimens only provide partial immunity or require booster immunizations at rather short intervals. To improve vaccination regimes as well as to develop novel strategies, it is vital to comprehend the process of protective antibody generation in humans.

Antibodies are produced by plasma cells, which reside in long-term survival niches such as the bone marrow, the spleen and mucosal tissues, where they ideally provide protective and lifelong levels of antibodies [2]. Concurrently, a second line of defence is formed by memory B cells, which have the ability to rapidly differentiate into antibodysecreting cells upon re-encounter of the pathogen. Their advantage is that they typically have a broader activity and are able to fine-tune their B cell receptor (BCR) specificity by their capability of re-entering germinal centres (GC). This allows memory B cells to recognize virus variants more efficiently [3-5]. Long-lived plasma cells and high-affinity memory B cells are typically generated in secondary lymphoid organs (SLO) during the GC reaction. This reaction critically relies on follicular helper $\mathrm{T}$ cells (Tfh), which drive B cell activation, proliferation, selection of high-affinity clones and differentiation into long-lived plasma cells or memory B cells [5-7]. Therefore, the ideal vaccine scheme not only relies on optimal B cell receptor epitopes but should also perfectly stimulate antigen-specific Tfh cells. 


\section{Generation of Tfh Cells in SLO}

The spatially highly organized structure of SLO accommodates specific micro-anatomical environments that provide the necessary signals for Tfh cell differentiation [8]. T and B cell zones are organized by stromal cell subsets producing the chemokines CCL19/CCL21 or CXCL13, and by $\mathrm{T}$ and $\mathrm{B}$ cells expressing the corresponding chemokine receptors (CCR7 and PSGL-1 or CXCR5) [8]. During their generation from naive CD4 ${ }^{+} \mathrm{T}$ cells, Tfh cells migrate through different SLO compartments, which provide unique signals and drive the differentiation from pre-Tfh to GC Tfh cells.

Within the $T$ cell zone, naive $T$ cells are primed by contact with dendritic cells (DC) presenting their specific antigen [9-11]. At this early stage, fate commitment to the Tfh cell or alternative Th lineages, such as Th1, Th2, or Th17, is already determined. T cell fate critically depends on several cytokine pathways (Figure 1). For example, Tfh cell fate is facilitated by STAT3 [12] and inhibited by STAT5 signalling [13,14], while STAT1 signalling dictates a Th1 fate [15]. Hence, the cytokines IL-6 and IL-21, both connected to STAT3 signalling, promote Tfh differentiation [16-18], whereas IL-2-mediated STAT5 signalling inhibits upregulation of the lineage-defining transcription factor Bcl-6. Interestingly, Tfh cell precursors are themselves producers of IL-2 but do not express IL-2R $\alpha[19,20]$. In this context, IL-2 acts only in a paracrine fashion on neighbouring Th1 cell precursors, promoting the early fate of Tfh and Th1 cell development. In contrast, IL-21 as the major cytokine produced by Tfh cells, generates a positive feed-forward loop for Tfh cell generation [16,21]. The Tfh/Th1 fate decision is further reinforced by a direct and reciprocal inhibition of the two lineage-defining transcription factors, T-bet and Bcl-6 [22-27]. Therefore, modulation of the specific cytokine milieu might be a potential therapeutic way to boost or counteract early Tfh cell differentiation. In mouse models, neutralization of or supplementation with IL-2 successfully promoted or inhibited Tfh differentiation, respectively $[13,14]$. Moreover, the use of adjuvants that induce IL- 6 production by DC could be a prospective blueprint to foster Tfh cell differentiation (see below).

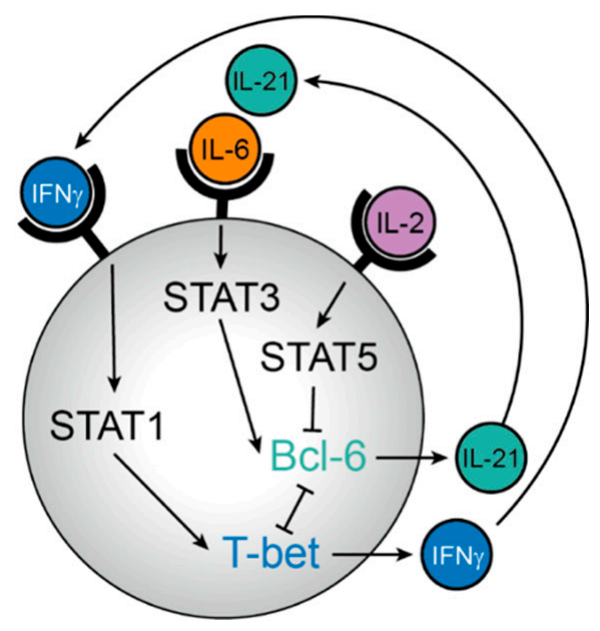

Figure 1. Regulation of $\mathrm{T}$ follicular helper (Tfh) versus $\mathrm{T}$ helper-1 (Th1) differentiation by cytokine signals. Induction of the Tfh cell master transcription factor Bcl-6 critically relies on binding of the transcription factor STAT3 (induced via interleukin- (IL-) 6 and IL-21) to its promoter and is inhibited by STAT5 (induced via IL-2). STAT5 does not only inhibit STAT3 binding to the Bcl6 locus, but additionally induces the transcription factor Blimp-1, a direct antagonist of Bcl-6, thus promoting the development of non-Tfh effector T cells such as Th1 cells. As an additional feed-forward loop, the Th1 master transcription factor T-bet forms a repressive complex with Bcl- 6 and inhibits a number of genes important for further Tfh cell development.

Pre-Th1 cells upregulate their chemokine receptor CXCR3, which primes them for lymph node exit and migration into inflamed tissues [28]. In contrast, pre-Tfh cells concomitantly upregulate CXCR5 and downregulate CCR7, leading to their migration towards 
the border between T and B cell zone [29,30]. A specific cytokine milieu at the T/B border further promotes Tfh cell differentiation. This region is rich in a special subpopulation of IL-2R ${ }^{\text {high }}$ DCs, which act as a molecular sink for IL-2 [31]. In addition, these DC produce large amounts of IL-6 [32], which altogether provides the optimal environment for Tfh cell differentiation.

In parallel, cognate naive $\mathrm{B}$ cells are activated and migrate to the $\mathrm{T} / \mathrm{B}$ border, facilitated by the reverse downregulation of CXCR5 and upregulation of CCR7 [33]. This strategical migration process enables the first interaction between antigen-specific $\mathrm{T}$ and $\mathrm{B}$ cells. Additionally, activated B cells, which highly express IL-2R $\alpha$, contribute to the low IL2 levels at the T/B border and provide additional specific signals for further Tfh cell development, since mature Tfh cells are not generated in the absence of B cells [29]. Despite the fact that many of these processes are still not fully understood, one considerably acknowledged process is T cell co-stimulation via ICOS ([34], see below).

GC structures develop within the B cell zone and resemble highly organized microstructures in which $\mathrm{T}$ and $\mathrm{B}$ cell cooperation takes place. The positioning of GC is predefined by the presence of follicular dendritic cells (FDC), a stromal cell population producing CXCL13, which is the chemoattractant for CXCR5-expressing Tfh and B cells [35]. Additionally, this cell population has the unique property of capturing native antigens for a prolonged time to support the ongoing selection of B cells [36]. Only a fraction of Tfh cells develop into GC Tfh cells, which are characterized by the highest expression of CXCR5, PD-1, and IL-21 [29]. The remaining Tfh cells reside in the B cell zone, but only outside the GC structure or in interfollicular regions [37-39]. As previously mentioned, the particular signals that program a Tfh cell to evolve into GC Tfh cells are still inconclusive.

Within the GC, Tfh cells provide B cell help mainly through the production of IL-21 and CD40L, which are two major factors for B cell activation and differentiation [40]. Since the number of GC Tfh cells is much lower than the number of GC B cells, the availability of $\mathrm{T}$ cell help is the rate-limiting step for B cell selection. Only B cells with a high-affinity B cell receptors can efficiently capture antigens and present MHC class II/peptide complexes in high density, which in turn provides them with the best $\mathrm{T}$ cell help [41-43]. Dependent on received Tfh cell-mediated signals, GC B cells either undergo further rounds of somatic hypermutation to increase BCR affinity or leave the germinal centre to differentiate into long-lived antibody-producing PCs or memory B cells. B cells that lose antigen specificity undergo apoptosis [40]. Moreover, recent data proved a similar Tfh cell clonal selection based on TCR affinity and antigen availability [44]. After the termination of the GC reaction, memory Tfh cells can either remain in the lymphoid organ in which they have been generated $[37-39,45]$ or turn into a circulating memory Tfh (cTfh) cell population (see below) (Figure 2).

Classical Tfh cells are generated in SLO, whereas in non-lymphoid tissues, Tph cells are typically the population providing help for the local differentiation of $\mathrm{B}$ cells into plasma cells. Memory Tfh, Tph and B cells can remain in SLO and non-lymphoid tissues. However, they are also found as circulating populations in the peripheral blood.

Apart from cytokines and chemokine receptors, costimulatory receptors are an additional attractive therapeutic target for modulating Tfh cell generation. Costimulatory signalling via CD28 is important for the very early upregulation of the transcription factor Bcl-6 in pre-Tfh cells [46,47], and the treatment of autoimmune patients with the CD28 costimulation inhibitor Abatacept results in reduced frequencies of Tfh cells [48]. Signalling via the inducible T cell co-stimulator ICOS is mandatory for the progression of pre-Tfh to fully differentiated Tfh cells $[34,46,49,50]$. Follicular mantle B cells exhibit high levels of ICOS-L, and intravital imaging studies have shown that close contact via ICOS/ICOS-L is required for full Tfh cell maturation [34,51]. Once a stable Tfh phenotype has developed, sustained signalling via ICOS is required to maintain the Tfh cell phenotype. Furthermore, experimental blockade of ICOS signalling results in a rapid upregulation of the transcription factor Klf2, subsequent downregulation of CXCR5 and other receptors important for Tfh cell localization in the B cell follicle, and ultimate cell relocation back to the $\mathrm{T}$ cell 
zone [46]. Upregulation of CXCR5 via ICOS is directly counteracted by signalling via PD-1, which contributes to the fine-positioning of T cells within the B cell follicle [52]. As another positive co-stimulator, signalling via OX40 has been shown to upregulate several Tfh-associated molecules [53].

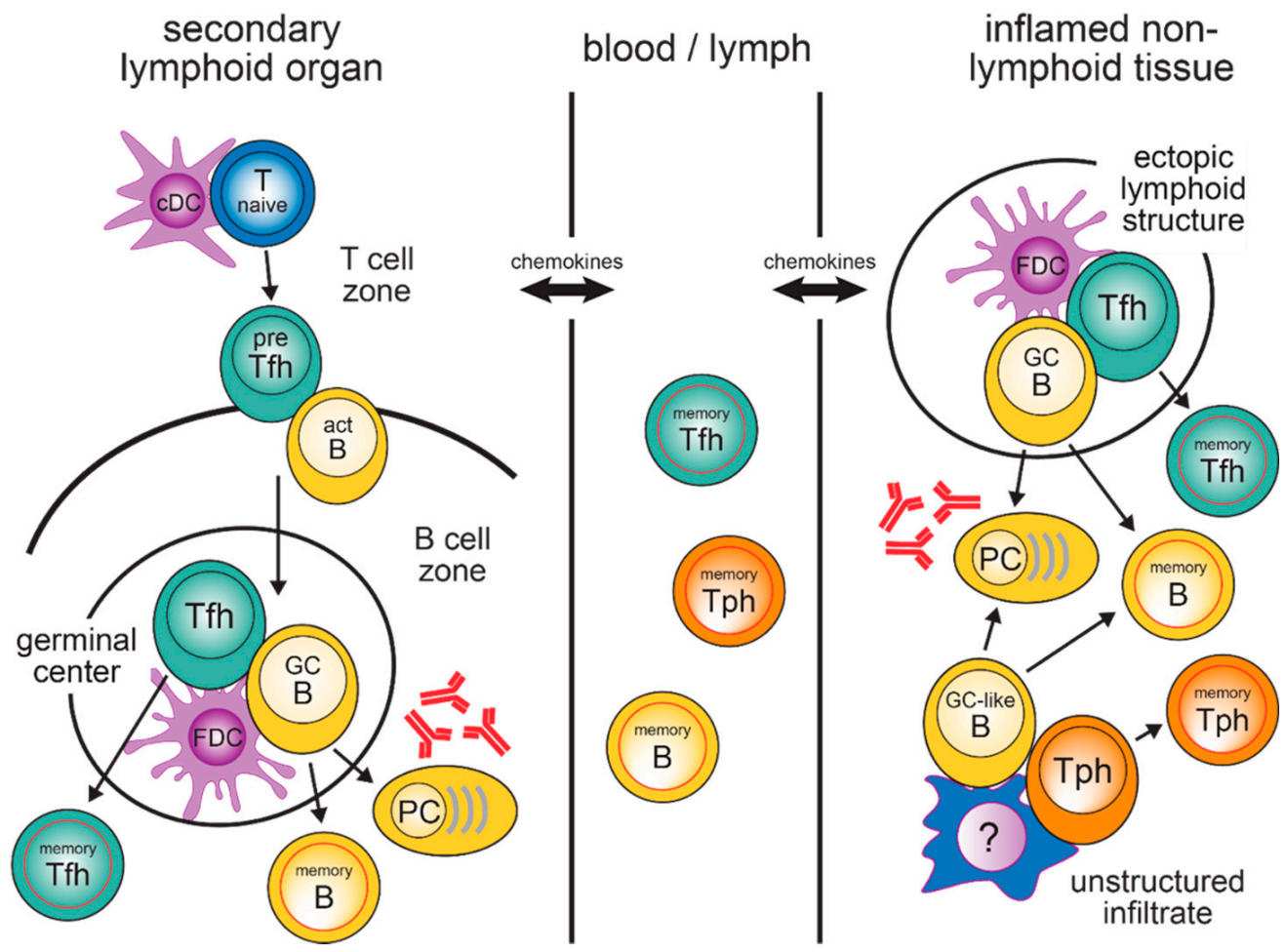

Figure 2. T cell/B cell cooperation in secondary lymphoid organs and inflamed non-lymphoid tissues. Abbreviations: act B, activated B cell; $\mathrm{CDC}$, conventional dendritic cell; FDC, follicular dendritic cell; GC B, germinal centre B cell; PC, plasma cell; pre-Tfh, precursor Tfh cell; Tfh, follicular helper T cell; Tph, peripheral helper T cell.

\section{Circulating Tfh Memory Cells in the Blood}

Originally, Tfh cells were considered a terminally differentiated effector cell population, whose life span ends upon termination of the GC reaction. Although CXCR5 ${ }^{+} \mathrm{CD} 4^{+} \mathrm{T}$ cells in human peripheral blood were first described in 1994 [54], their relation to Tfh cells in SLO was not completely understood because T cells in the blood lack the lineage-defining transcription factor Bcl-6. This is a marked difference from Th1 or Th2 memory cells, which retain expression of T-bet and GATA3 also in the peripheral blood. Only in 2012, after using adoptive transfer mouse models, it was experimentally demonstrated that Tfh memory cells exist and can rapidly regain their original phenotype, including Bcl-6 expression, upon restimulation [37,55-57]. Despite this finding, other studies showed that mutations in ICOS [58], STAT3 [59], CD40L [60], or BTK [61] not only reduce the frequency of GC Tfh cells but also affect the number of cTfh cells initially suggested a common origin. Recent studies comparing tonsillar Tfh cells to donor-matched peripheral blood Tfh cells revealed clonal overlap and influenza-specific cTfh cell clones in both organs [62]. Consistently, analyses of phenotype, transcriptome, epigenetics, and TCR clonotypes of cTfh cells and Tfh cells from thoracic duct lymph support the hypothesis that Tfh cells exit LN into the blood via the thoracic duct [63]. Nevertheless, $C X C R 5^{+} \mathrm{T}$ cells in blood are often referred to only as "Tfh-like" cells, whereby memory Tfh or cTfh cells describe their biological function much better.

Recently activated cTfh cells, which have just emigrated from the SLO, are characterized by high expression of ICOS and PD-1. Concomitantly, they also express higher levels 
of CD38, c-MAF and Ki-67 in combination with low CCR7 expression [55,56,64] and most strongly support B cell activation and differentiation in in vitro assays $[55,56]$.

In addition to their activation status, cTfh cells have been further subdivided into three subsets according to the differential expression of chemokine receptors [65]. CXCR3 ${ }^{+} \mathrm{CCR} 6^{-}$ cTfh cells are referred to as cTfh 1 cells and additionally express T-bet and secrete IFN- $\gamma$. CXCR3 ${ }^{-}{ }^{-}$CR6 ${ }^{-}$cTfh 2 cells express GATA3 and secrete IL-4, IL-5, IL-13. Moreover, cTfh2 cells are associated with class switch promotion to IgG and IgE. CXCR3 ${ }^{-} \mathrm{CCR}^{+}{ }^{+}$cTfh 17 cells express ROR $\gamma \mathrm{t}$ and are distinguished by the cytokine secretion of IL-17A, IL-17F and IL-22, promoting the generation of IgG and IgA [65]. Using coculture assays with naive B cells, cTfh2 and cTfh 17 were shown to efficiently stimulate B cell proliferation and antibody generation via IL-21 production $[56,65]$, whereas this was not the case for cTfh1 cells $[65,66]$. However, cTfh1 cells can efficiently provide help for memory B cells [67-69]. Therefore, it is unclear whether this subset discrimination has relevance in vivo, as antigenspecific memory Tfh cells should always be accompanied by memory B cells. Moreover, in $\mathrm{HCV}$-infected patients, $\mathrm{CXCR}^{+}$cTfh cells, but not their CXCR3 ${ }^{-}$counterparts, were shown to positively correlate with HCV-neutralizing antibody titers [69]. In addition, many IL-21/IFN- $\gamma$ co-producing Tfh cells have been found in autoimmune and other inflammatory diseases [70-73].

Due to the limited access to human lymphoid tissue and the herein resulting difficulty to study ongoing immune responses in humans, most knowledge about Tfh cells has been obtained from mouse models. However, both resting and recently activated cTfh cells have been shown to be suitable biomarkers to detect infections, vaccination outcome success and the quality of memory responses. Elevated levels of activated cTfh cells positively correlate with protective antibody levels, plasmablasts, and memory cell formation [64,67-69,74-76]. Furthermore, increased cTfh cells are thought to reflect erroneous Tfh cell responses in autoimmune disorders, since a positive correlation has been observed with serum autoantibody titers, disease activity, and severity $[55,77,78]$.

\section{4. $T$ and $B$ Cells in Inflamed Tissues}

$\mathrm{T}$ and $\mathrm{B}$ cells are not only found in SLO but also in many inflamed non-lymphoid tissues (Figure 2). Strong immune-activating conditions, such as influenza infection of the lung, promote the development of so-called ectopic lymphoid structures (ELS) that include $\mathrm{T}$ and $\mathrm{B}$ cell infiltrates and are also referred to as tertiary lymphoid tissue or inducible bronchus-associated lymphoid tissues (iBALT) in the lung. ELS functionally and structurally fully resemble their counterparts in SLO, which includes separated $\mathrm{T}$ and $\mathrm{B}$ cell zones, an FDC network, and the presence of classical Tfh- and GC B cells. In mice lacking all SLO, iBALT structures were sufficient to generate high levels of antibodies [79].

However, not all lung pathogens induce iBALT; for example modified vaccinia virus does, but this is not the case for P. aeruginosa [80]. Additionally, only few B cells and no FDC-containing ELS were detected in the lungs of severe COVID-19 patients [81-84]. The same applies to autoimmune and other chronic inflammatory diseases [85]. However, active T/B cooperation can also take place in FDC-negative disordered infiltrates, resulting in the local generation of GC-like B cells and antibody-producing plasma blasts [86]. How this is particularly organized, e.g., which cell types take over the function of FDC for antigen presentation, is still not clear. These responses are driven by tissue-resident $\mathrm{Tfh}-$ like cells that are characterized by high expression of PD-1 but lack of CXCR5 and Bcl-6. They provide potent $\mathrm{B}$ cell help due to their high expression of CD40L and production of IL-21 $[86,87]$ and often express chemokine receptors for homing into inflamed tissues such as CCR2 and CX3CR1 [88,89].

These Tfh-like cells, also recently termed peripheral $\mathrm{T}$ helper cells (Tph), have now been identified in a variety of inflamed non-lymphoid human tissues, such as the joints of rheumatoid arthritis patients [88], the skin in systemic sclerosis [90,91] and pemphigus [92], the kidney in lupus nephritis [89], intestinal tissue in celiac disease [91], nasal polyps [93], salivary glands in Sjögren's syndrome [94,95], the lung of sarcoidosis patients [96] and 
peritumoral tissue of breast cancer patients [97]. Although their presence in inflamed non-lymphoid tissues is a key feature of Tph cells, similar to Tfh cells, they can also be found as a circulating memory population in the peripheral blood, which seems to reflect an ongoing immune response in the inflamed tissue $[88,91,94-96]$.

$\mathrm{T}$ and $\mathrm{B}$ cells in non-lymphoid tissues should not only be considered as a pathogenic cell population in autoimmune diseases. In barrier organs, such as lung or gut, they also provide a very efficient first line of defence against invading pathogens. Tissueresident memory $\mathrm{T}(\mathrm{Trm})$ and $\mathrm{B}(\mathrm{Brm})$ cells have now been defined as an independent non-recirculating lineage, best characterized by their permanent expression of CD69, which antagonizes the lymphocyte exit receptor S1PR1 [98]. Although non-lymphoid tissues are typically dominated by $\mathrm{CD}^{+} \mathrm{Trm}$, viral and non-viral infections in barrier organs also induce $\mathrm{CD}^{+} \mathrm{Trm}$, which could be important for B cell help. This has been shown for mouse infection models [99,100] as well as human tissues [101-103]. A well-studied mouse model is influenza infection. This strong viral infection induces long-lasting iBALT structures containing Tfh as well as B cells within the lung tissue [104]. T and B cells can survive as tissue-resident memory cells for prolonged times and provide efficient protection from re-infection [105-111].Upon re-infection, lung-resident memory B cells rapidly develop into antibody-producing plasmablasts $[109,111]$. They also have a broader $B$ cell receptor repertoire than B cells in the lung-draining lymph nodes and are therefore superior in generating neutralizing antibodies against viral escape mutants [4]. Similar observations were made for other airborne pathogens like M. tuberculosis, a mouse adapted SARS coronavirus, and S. pneumoniae [112-114].

However, lung-resident memory $\mathrm{T}$ and $\mathrm{B}$ cells are not a unique feature for severe viral infections and do not require the development of iBALT. In addition, in a protein immunization-based interstitial lung inflammation mouse model, tissue-resident memory Tph and B cells can be generated. Importantly, they are highly enriched in $\operatorname{Ig} \mathrm{A}^{+}$ memory cells, which is the exact isotype required for the effective protection of mucosal surfaces [86]. In T cell-specific Bcl6 knock-out mice, which completely lack Tfh cells, protective neutralizing antibody levels can also be generated in an influenza vaccination setting [115]. Although it is not clear yet whether memory Tph cells are equally effective in driving memory B cell re-activation as classical Tfh cells, this is an important notion for the development of vaccination strategies.

\section{Vaccination Strategies to Promote Tfh Cell Development}

The production of Tfh cells can be manipulated at various levels, including cytokine milieus and costimulatory receptors. A rather simple and already widely used strategy to enhance antibody responses is the use of adjuvants in vaccination. Adjuvants act in two different ways: first, they contain specific immunostimulators to activate the innate immune system. These immunostimulatory ligands mimic pathogen- or damage-associated molecular patterns and include, for example, Toll-like receptor (TLR) agonists or C-type lectin receptor (CLR) agonists. These agonists stimulate DCs which subsequently enhance their antigen-presentation capacity [116-118]. At the same time, a proinflammatory cytokine milieu is generated, including cytokines such as IL-6, which foster Tfh cell development [32,119-121]. Second, many adjuvants exhibit a depot function for the immunogen. This is important since-unlike infectious agents that replicate in the body-vaccines are only bioavailable for rather a short time. This time can be prolonged by an adjuvant that slowly, but steadily releases antigens since the maintenance of Tfh cells is highly dependent on prolonged antigen availability $[37,122]$. Repeated injections of peptides have been able to overcome the normally limited antigen presentation by DCs and resulted in higher frequencies of Tfh cells [123]. A similar effect can be achieved with adjuvants, which have a very good depot function. In this situation, water in oil emulsions, which are more stable than oil in water emulsions, usually provide the best results $[124,125]$. Micro-osmotic pumps, which are implanted under the skin and constantly release their 
substance, also guarantee prolonged antigen availability and result in more than 10-fold increased antibody levels compared to a single bolus injection [126].

However, adjuvant use in humans remains very limited, mainly due to safety concerns [127-130]. Table 1 lists adjuvants that are currently in use, being tested in clinical trials, or of research interest, and describes their influence on Tfh cells. The most commonly used adjuvant in humans is still alum, and this adjuvant was used in vaccinations as early as the beginning of the 20th century [131]. Only within recent years, modern and more complex formulations such as MF59, the adjuvant systems (AS) AS01, AS03, AS04, and cytosine phosphoguanosine $(\mathrm{CpG})$ have been approved for human vaccination.

Table 1. Adjuvants and their influence on Tfh cells.

\begin{tabular}{|c|c|c|c|c|c|}
\hline \multicolumn{3}{|c|}{ Adjuvant } & Influence on Humoral Immune Response & $\begin{array}{l}\text { Licensed in } \\
\text { Humans }\end{array}$ & Literature \\
\hline \multirow{2}{*}{$\underset{\Xi}{\Xi}$} & \multicolumn{2}{|r|}{ alum } & $\begin{array}{l}\text { Tfh cell formation but lower numbers compared to } \\
\text { combinations with TLR agonists }\end{array}$ & licensed & {$[128,132,133]$} \\
\hline & \multicolumn{2}{|c|}{ AS04 (MPL + alum) } & $\begin{array}{l}\text { in combination with MPL strong activation of T and B cells, } \\
\text { persistent antibody, and cellular responses, induces biased } \\
\text { Th1 immune responses } \rightarrow \text { targeting of viral infections }\end{array}$ & licensed & {$[127,134-136]$} \\
\hline \multirow{5}{*}{ 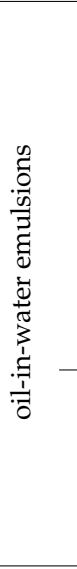 } & \multicolumn{2}{|r|}{ MF59 } & promotion of potent immune responses in mice and humans & licensed & {$[137,138]$} \\
\hline & \multicolumn{2}{|c|}{$\begin{array}{l}\text { AS03 (resembles MF59, } \\
\text { combined with vitamin E) }\end{array}$} & $\begin{array}{l}\text { potent Tfh cell activation in mice, high proportion of } \\
\text { high-avidity antibodies after antigen recall in humans, } \\
\text { persistence of cellular and humoral responses, induces } \\
\text { marked antibody response, used in vaccines where } \\
\text { antibody mediated protection is important }\end{array}$ & licensed & {$[127,139,140]$} \\
\hline & \multicolumn{2}{|c|}{ GLA-SE (GLA + squalene) } & $\begin{array}{l}\text { promotes Tfh cell expansion in mice and men and effective, } \\
\text { long-lived antibody production in humans, stable } \\
\text { emulsion superior in enhancing adjuvanticity in GLA }\end{array}$ & clinical trials & {$[128,141,142]$} \\
\hline & \multicolumn{2}{|c|}{ SLA-SE (SLA + squalene) } & strong antibody and $\mathrm{CD}^{+} \mathrm{T}$ cell responses in mice & & {$[143,144]$} \\
\hline & \multicolumn{2}{|c|}{ AS02 (MPL + QS-21) } & $\begin{array}{l}\text { induces strong humoral and } \mathrm{T} \text { cell mediated immune } \\
\text { responses, used for pathogens that require strong } \mathrm{T} \\
\text { cell response, enhances humoral immune response } \\
\text { in elderly people }\end{array}$ & clinical trials & {$[127,145]$} \\
\hline \multirow{2}{*}{ 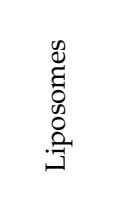 } & \multicolumn{2}{|c|}{ AS01 (MPL + Saponin) } & $\begin{array}{l}\text { persistence of cellular and humoral responses in humans, } \\
\text { robust innate stimulation, highly potent stimulation of } \\
\mathrm{CD}^{+} \mathrm{T} \text { cells and specific antibody responses in humans, } \\
\text { designed to strengthen } \mathrm{CD}^{+} \mathrm{T} \text { cell response }\end{array}$ & licensed & {$[127,140,146,147]$} \\
\hline & \multicolumn{2}{|c|}{$\begin{array}{l}\text { AS015 (AS01 combined } \\
\text { with CpG) }\end{array}$} & $\begin{array}{c}\text { CpG promotes Tfh cell and antibody responses to } \\
\text { influenza vaccination }\end{array}$ & not licensed & {$[148]$} \\
\hline \multirow{3}{*}{ 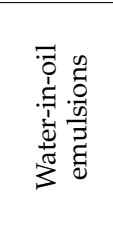 } & \multicolumn{2}{|r|}{ IFA } & $\begin{array}{c}\text { strong Tfh cell polarization in mice, strong side effects in } \\
\text { humans and therefore not used, addition of CpG improved } \\
\text { Tfh cell differentiation }\end{array}$ & not licensed & {$[124,149,150]$} \\
\hline & \multicolumn{2}{|r|}{ CFA } & $\begin{array}{l}\text { triggers Tfh cells and additionally Th1, Th17 and Th2 } \\
\text { responses in mice }\end{array}$ & not licensed & {$[124]$} \\
\hline & \multicolumn{2}{|c|}{ Montanide } & strong Tfh cell polarization in mice, side effects in humans & not licensed & {$[124,151]$} \\
\hline \multirow{6}{*}{ 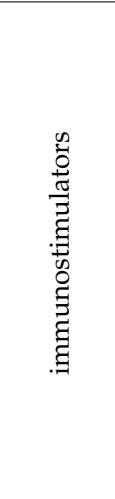 } & \multirow{5}{*}{ 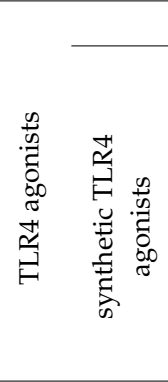 } & LPS & not usable for humans due to toxicity & & [152] \\
\hline & & $\begin{array}{l}\text { miltefosine (TLR4 } \\
\text { and TLR9 agonist) }\end{array}$ & $\begin{array}{l}\text { enhances Tfh cell responses and GC reaction in mice, } \\
\text { induces both Th1 and Th2 antigen-specific cytokine } \\
\text { responses, MTF improves efficacy of influenza vaccine } \\
\text { against homologous and heterologous viruses by } \\
\text { improving Tfh and antibody response, might be } \\
\text { used for other than influenza vaccines as well }\end{array}$ & & {$[153,154]$} \\
\hline & & MPL & included in AS01 and AS04 & & \\
\hline & & GLA & GLA-SE & & \\
\hline & & SLA & SLA-SE & & \\
\hline & 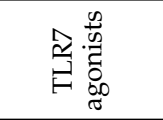 & 3M052 & $\begin{array}{c}\text { promotes DC maturation and cellular response, enhanced } \\
\text { Tfh cell generation compared to alum in NHP }\end{array}$ & & {$[152,155,156]$} \\
\hline
\end{tabular}


Table 1. Cont.

\begin{tabular}{|c|c|c|c|c|}
\hline \multicolumn{2}{|c|}{ Adjuvant } & Influence on Humoral Immune Response & $\begin{array}{l}\text { Licensed in } \\
\text { Humans }\end{array}$ & Literature \\
\hline \multirow{2}{*}{ 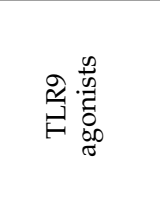 } & CpG & $\begin{array}{l}\text { included in AS015, combination of SARS-CoV-2 spike } \\
\text { protein with CpG } 1018 \text { and alum elicited Th1-dominant } \\
\text { immune responses with high neutralizing antibodies in } \\
\text { mice }\end{array}$ & & {$[157]$} \\
\hline & IC31 & $\begin{array}{c}\text { induction of strong Th1 response in mice and humans, } \\
\text { increase in Tfh cells in mice }\end{array}$ & clinical trials & {$[158,159]$} \\
\hline 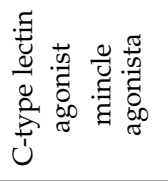 & CAF01 & $\begin{array}{l}\text { promotes GC responses and prolonged humoral responses } \\
\text { in murine neonates, strong Th1/Th17 responses in mice }\end{array}$ & \multirow[t]{2}{*}{ clinical trials } & {$[158,160]$} \\
\hline 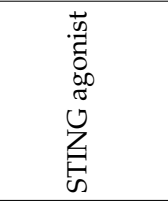 & $\begin{array}{l}\text { chemically } \\
\text { modified cyclic } \\
\text { dinucleotide }\end{array}$ & $\begin{array}{c}\text { induces Tfh and Th1 cell responses in neonatal cord blood, } \\
\text { three-dose vaccination schedule is beneficial in mice } \\
\text { leading to higher antibody titres; } \\
\text { presence of cGAMP within HIV-derived virus-like particles } \\
\text { enhanced adaptive immune responses, increased Tfh cell } \\
\text { numbers in draining lymphnode }\end{array}$ & & {$[161,162]$} \\
\hline \multicolumn{2}{|r|}{$\underset{⿱}{\rightleftarrows}$} & $\begin{array}{c}\text { Study in NHP, HIV model: Activin A administration } \\
\text { shows no differences in Tfh cell numbers, but decreased } \\
\text { number of Tfr cells } \rightarrow \text { either by promotion of Tfh cells or } \\
\text { inhibitory role on Tfr development, improved antibody } \\
\text { response and PC development }\end{array}$ & & {$[163]$} \\
\hline \multicolumn{2}{|r|}{ 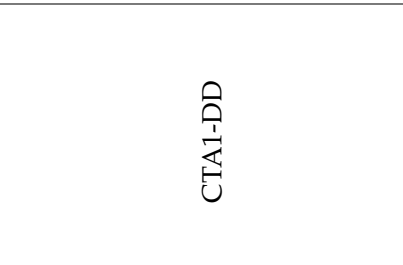 } & $\begin{array}{l}\text { CTA1-DD adjuvant well documented in mice, long term } \\
\text { plasma cell and memory B cell development } \\
\text { Effective mucosal and systemic adjuvant } \\
\text { Can bind complement on FDCs, thereby directly affects } \\
\text { DC function, directly influences gene transcription in } \\
\text { FDCs, greatly upregulates Cxcl13 gene expression } \\
\rightarrow \text { strongly promotes GC B cell and Tfh cell } \\
\text { development in neonate mice }\end{array}$ & & {$[164-167]$} \\
\hline \multicolumn{2}{|r|}{ 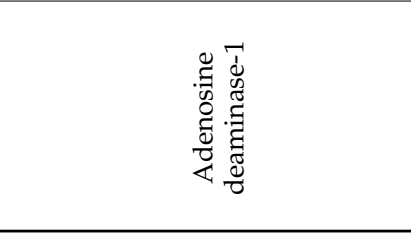 } & $\begin{array}{l}\text { HIV-1 envelope (env) DNA vaccine: co-immunization with } \\
\text { plasmid-encoded adenosine deaminase- } 1 \text { in the context of } \\
\text { an HIV-1 env DNA vaccine increases draining lymphnode } \\
\text { Tfh cell frequencies and increases env-binding antibody in } \\
\text { the serum of vaccinated mice } \rightarrow \text { no increase in Tfh cell } \\
\text { numbers compared to other groups but enhanced Tfh } \\
\text { effector functions (increased serum antibody levels) }\end{array}$ & & {$[168]$} \\
\hline
\end{tabular}

Abbreviations: AS, adjuvant system; CAF, cationic adjuvant formulation; CFA, Complete Freund's adjuvant; cGAMP, cyclic guanosine monophosphate-adenosine monophosphate; CTA1-DD, cholera toxin A1 subunit (CTA1) fused via its C-terminal end to a dimer of the Ig-binding D region (DD); GLA-SE, glucopyranosyl lipid adjuvant-stable emulsion; IFA, incomplete Freund's adjuvant; LPS, lipopolysaccharide; MPL, monophosphoryl-lipid-A; MTF, miltefosine; QS-21, plant extract derived from Quillaja saponaria; SLA-SE, second-generation lipid adjuvant formulated in a stable emulsion; Tfr, follicular regulatory T cell; TLR, toll-like receptor.

The adjuvant alum induces robust $\mathrm{CD} 4^{+} \mathrm{T}$ cell and antibody responses [169], the effect of which has mostly been attributed to a depot effect, but which appears not to be required for adjuvant efficiency [170]. Besides this fact, alum strongly activates different pathways of the innate immune system (reviewed in [171-173]). An alum-containing adjuvant system is AS04, which consists of the TLR4 agonist 3-O-desacyl-4'-monophosphoryl lipid A (MPL) adsorbed to alum salts. The MPL adjuvant prolongs innate and humoral immune responses [135,136]. The adjuvants MF59 and AS03 are oil-in-water emulsion-based adjuvants and show improved tolerance compared to water-in-oil emulsions $[149,174]$. MF59 shows improved antigen uptake at injection sites [175] and induces strong antibody and T cell responses [176]. At the same time, AS03 is based on MF59 with the addition of DL- $\alpha$-tocopherol, a bio-available form of vitamin $\mathrm{E}$, promoting strong $\mathrm{T}$ and $\mathrm{B}$ cell responses [177]. CpG-ODN is a TLR agonist-based adjuvant that supports immunostimulatory effects of antigens and increases antigen-presenting cell activation [178,179]. Lastly, the liposome-based adjuvant system AS01 contains MPL as additional TLR4 agonist and elicits strong cellular and humoral immune responses [180,181].

In addition to the importance of using adjuvants, recent studies show an increase in Tfh and B cell responses by targeting Tfh-cell specific molecules. The addition of Fc-fused IL-7 to an influenza vaccine not only promoted Tfh and B cell responses in mice and 
cynomolgus monkeys, but also reduced the dose required for the generation of protective antibody levels [182]. The administration of a recombinant rabies virus expressing OX-40L promotes Tfh cells, GC B cells, and plasma cells and thus the protective antibody response in mice proposing OX-40L as a novel adjuvant strategy [183]. Besides Tfh cells, recent studies have demonstrated that the targeting of antigen-presenting cells is also beneficial. Antigen-fused monoclonal antibodies against DEC205, a surface receptor on a subset of DC, induced Tfh cell differentiation and strong B cell responses in mice [184]. HIV-1vaccinated humanized mice showed enhanced B cell and memory Tfh cell responses after CD40-targeted boost vaccination [185], and targeting of antigen to MHCII molecules in mice significantly increased DC- and B cell-mediated presentation of p:MHCII, resulting in enhanced GC responses [186].

Another key aspect is the delivery of the vaccine. A study of malaria vaccination in non-human primate (NHP) models showed improved antigen-specific T and B cell responses in poly(lactic-co-glycolic acid)- (PLGA)-based synthetic vaccine particles (SVPs), co-administered with TLR-based adjuvants, compared to antigens delivered by liposomal formulations. One benefit of SVPs is their slow degradation and associated antigen retention in the lymph node [187]. In another study, nanoparticles of multilamellar lipids carrying the VMP001 antigen of the malaria-causing Plasmodium vivax promoted a broad humoral immune response in mice compared to vaccinations with soluble antigen or alum. Once more, nanoparticles showed improved antigen retention in draining lymph nodes [188].

A comparative study of three vaccines against HIV, zika virus and influenza virus

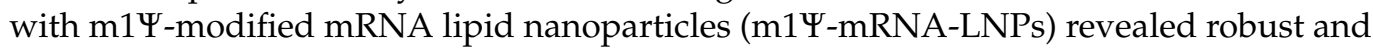
enhanced induction of Tfh cells, GC B cells, and neutralizing antibody responses compared to inactivated virus and adjuvanted protein vaccines in mice and NHPs. This may be due to sustained antigen presentation and additional adjuvant effects by mRNA-LNPs themselves [189]. These findings were confirmed in a recent study, comparing a SARSCoV2-mRNA vaccine encoding the receptor-binding domain (RBD) and full-length spike protein of SARS-CoV2 with recombinant RBD protein (rRBD), formulated with the conventional adjuvant AddaVax. The mRNA vaccine showed superior ability to induce Tfh cell induction, GC B cell responses, and higher levels of neutralizing antibodies, likely due to prolonged antigen presentation [190].

Consideration of time delay and dosage of vaccination is equally critical. In NHPs, longer intervals between prime and booster immunization lead to increased GC B cell frequencies and neutralizing antibody titres [191]. The use of a continuous immunization strategy, for example via osmotic pumps, showed substantial advantages over conventional bolus immunization in both NHP and mouse models [126,191,192]. The positive effect of delayed fractional dose boosting on immune responses was confirmed in human studies with a malaria vaccine [193].

Given the fact that pathogens enter the organism via barrier organs, the generation of tissue-resident memory cell populations as a first line of defence should be an important strategy for the development of vaccination regimes. Although systemically or subcutaneously administered immunizations were shown to induce tissue-specific protection [194,195], local immunization strategies such as intranasal, intravaginal, or oral antigen administration appeared to be beneficial.

Intranasal immunization strategies elicited potent humoral immune responses in the murine lung, including high antigen-specific IgA levels and memory B cells [196,197]. Moreover, intratracheal administration of a polysaccharide-adjuvanted vaccine showed improved protection against aerosol $M$. tuberculosis infection in mice compared to parental administration. This could be attributed to the successful induction of lung-resident memory T cells [198]. Another study demonstrated the generation of lung-resident CD4 ${ }^{+}$memory T cells and protection against tuberculosis infection upon intranasal immunization with a recombinant influenza A viruses (rIAV) vaccine expressing M. tuberculosis peptides [199]. Moreover, supportive effects were seen in intravaginal administration [200,201]. In addi- 
tion to effective memory $\mathrm{T}$ cell generation, orally administered inactivated enterotoxigenic E. coli vaccine in humans showed significantly increased levels of activated cTfh cells, which not only secreted increased levels of IL-21 but also expressed integrin 137 , indicating gut homing potential. Additionally, intestine-derived memory IgA responses were detected [202].

However, mucosa-based vaccination strategies also have some disadvantages. For safety reasons, the use of subunit vaccines is preferred. Yet, these require larger amounts of antigens to, for example, compensate for degradation in the gastrointestinal tract. Besides, there is need for adjuvants and delivery systems that allow local uptake by antigenpresenting cells [203]. This can be overcome by adapting the mode of delivery. Combined delivery of antigen and adjuvant on the same nanoparticle demonstrated increased frequencies of antigen-specific CD8 ${ }^{+}$tissue-resident $\mathrm{T}$ cells in the lung [204] and liposome-based vaccines proved to be more easily absorbed via the lungs, thereby activating alveolar macrophages [205].

Given the known importance of prolonged antigen availability for the effective generation of Tfh (see above) and in general memory cells, many strategies aim to improve antigen persistence. Intranasal administration of a biocompatible polyanhydride nanoparticlebased IAV vaccine (IAV-nanovax) generated effective humoral immune responses and $\mathrm{CD}^{+}$and $\mathrm{CD}^{+}$memory $\mathrm{T}$ cells via a long-lasting release of the antigen by surface erosion [206]. Recently, usage of alum adjuvant proved sustained antigen persistence as crucial for optimal tissue-resident memory cell induction in the lung [207], and another study unravelled the requirement of high amounts of antigens for the efficient generation of memory [208]. To prolong vaccine persistence, $\mathrm{pH}$-responsive polymers were successful to increase retention in pulmonary antigen-presenting cells [204]. Another strategy is the stimulation of cytokines that specifically promote tissue-resident T cells $[209,210]$. Intranasal immunization with distinct TLR agonists coated pathogen-like particles generated phenotypically and functionally distinct populations of effector and memory $\mathrm{T}$ cells in lungs and airways of mice [211].

Dietary aspects can also have a huge impact on vaccination. Micronutrients such as zinc, copper, iron, and vitamins A, C, and D support immune responses [212]. Therefore, the $\mathrm{WHO}$ recommends combining the measles vaccination with a vitamin A supplementation in high-risk areas [213,214]. In a mouse model, vitamin A signalling was shown to directly promote the Tfh cell development via retinoic acid receptor $\alpha$ [215]. Moreover, retinoic acid as an adjuvant was shown to induce CCR9 and $\alpha 4 \beta 7$ expression on antigen specific $\mathrm{CD}^{+} \mathrm{T}$ cells, thereby promoting migration to intestinal mucosal tissues. As a micronutrient, selenium is particularly important for Tfh cell survival [216]. Glutathion peroxidase 4 (GPX4) is a selenium-dependent enzyme and prevents Tfh cells from ferroptosis. Selenium supplementation of mice increased Tfh cell numbers and promoted antibody responses after influenza vaccination. Furthermore, the metabolic hormone leptin has an important function for successful vaccine responses [217]. Leptin activates STAT3 and mTOR signalling pathways, thereby promoting Tfh cell differentiation. Fasting-induced leptin deficiency reduced the protective effects of influenza vaccination in mice and could be specifically reversed by leptin supplementation.

\section{Conclusions}

Tfh cells are a key determinant for the generation of high-affinity memory B cells and plasma cells. Their successful induction should be equally considered in the development of vaccination strategies. Tfh generation is highly dependent on specific cytokine milieus, and the use of appropriate adjuvants might be a way to selectively regulate their numbers. In addition to classical Tfh cells, Tph cells are a novel $\mathrm{CD} 4^{+} \mathrm{T}$ cell population that provides $\mathrm{B}$ cell help in non-lymphoid tissues. Tfh, Tph, and memory B cells all exist as lymphoid tissueresident, non-lymphoid tissue-resident and circulating populations. At the same time, they have complementary roles in providing systemic and local protection. Tissue-resident Tph and memory B cells can play an important role as the first line of specific defence against 
pathogens in barrier organs such as the lungs. Therefore, it will be important to better understand the biology of tissue-resident memory $\mathrm{T}$ and $\mathrm{B}$ cells to find ways to specifically induce them for vaccination purposes.

Author Contributions: J.R.-J. and A.H., conceptualization and writing. Both authors have read and agreed to the published version of the manuscript.

Funding: This work was funded by grants from the Deutsche Forschungsgemeinschaft HU 1294/8-1 and TRR 130 TP23 to A.H.

Acknowledgments: We thank Laura Bauer for many helpful discussions and Rayane Atallah for critical reading of the manuscript.

Conflicts of Interest: The authors declare no conflict of interest.

\section{References}

1. Lu, L.L.; Suscovich, T.J.; Fortune, S.M.; Alter, G. Beyond binding: Antibody effector functions in infectious diseases. Nat. Rev. Immunol. 2018, 18, 46-61. [CrossRef]

2. Amanna, I.J.; Carlson, N.E.; Slifka, M.K. Duration of Humoral Immunity to Common Viral and Vaccine Antigens. N. Engl. J. Med. 2007, 357, 1903-1915. [CrossRef]

3. Purtha, W.E.; Tedder, T.F.; Johnson, S.; Bhattacharya, D.; Diamond, M.S. Memory B cells, but not long-lived plasma cells, possess antigen specificities for viral escape mutants. J. Exp. Med. 2011, 208, 2599-2606. [CrossRef]

4. Adachi, Y.; Onodera, T.; Yamada, Y.; Daio, R.; Tsuiji, M.; Inoue, T.; Kobayashi, K.; Kurosaki, T.; Ato, M.; Takahashi, Y. Distinct germinal center selection at local sites shapes memory B cell response to viral escape. J. Exp. Med. 2015, 212, 1709-1723. [CrossRef]

5. Akkaya, M.; Kwak, K.; Pierce, S.K. B cell memory: Building two walls of protection against pathogens. Nat. Rev. Immunol. 2020, 20, 229-238. [CrossRef]

6. McHeyzer-Williams, M.; Okitsu, S.; Wang, N.; McHeyzer-Williams, L. Molecular programming of B cell memory. Nat. Rev. Immunol. 2012, 12, 24-34. [CrossRef]

7. Dhenni, R.; Phan, T.G. The geography of memory B cell reactivation in vaccine-induced immunity and in autoimmune disease relapses. Immunol. Rev. 2020, 296, 62-86. [CrossRef] [PubMed]

8. Qi, H.; Kastenmüller, W.; Germain, R.N. Spatiotemporal Basis of Innate and Adaptive Immunity in Secondary Lymphoid Tissue. Annu Rev. Cell. Dev. Biol. 2014, 30, 141-167. [CrossRef] [PubMed]

9. Krishnaswamy, J.K.; Gowthaman, U.; Zhang, B.; Mattsson, J.; Szeponik, L.; Liu, D.; Wu, R.; White, T.; Calabro, S.; Xu, L.; et al. Migratory $\mathrm{CD} 11 \mathrm{~b}(+)$ conventional dendritic cells induce $\mathrm{T}$ follicular helper cell-dependent antibody responses. Sci. Immunol. 2017, 2, eaam9169. [CrossRef] [PubMed]

10. Goenka, R.; Barnett, L.G.; Silver, J.S.; O’Neill, P.J.; Hunter, C.A.; Cancro, M.P.; Laufer, T.M. Cutting Edge: Dendritic Cell-Restricted Antigen Presentation Initiates the Follicular Helper T Cell Program but Cannot Complete Ultimate Effector Differentiation. J. Immunol. 2011, 187, 1091-1095. [CrossRef]

11. Shin, C.; Han, J.-A.; Koh, H.; Choi, B.; Cho, Y.; Jeong, H.; Ra, J.-S.; Sung, P.S.; Shin, E.-C.; Ryu, S.; et al. CD8 $\alpha-$ Dendritic Cells Induce Antigen-Specific T Follicular Helper Cells Generating Efficient Humoral Immune Responses. Cell Rep. 2015, 11, 1929-1940. [CrossRef] [PubMed]

12. Eddahri, F.; Denanglaire, S.; Bureau, F.; Spolski, R.; Leonard, W.J.; Leo, O.; Andris, F. Interleukin-6/STAT3 signaling regulates the ability of naive T cells to acquire B-cell help capacities. Blood 2009, 113, 2426-2433. [CrossRef]

13. Ballesteros-Tato, A.; León, B.; Graf, B.A.; Moquin, A.; Adams, P.S.; Lund, F.E.; Randall, T.D. Interleukin-2 Inhibits Germinal Center Formation by Limiting T Follicular Helper Cell Differentiation. Immunity 2012, 36, 847-856. [CrossRef]

14. Johnston, R.J.; Choi, Y.S.; Diamond, J.A.; Yang, J.A.; Crotty, S. STAT5 is a potent negative regulator of TFH cell differentiation. J. Exp. Med. 2012, 209, 243-250. [CrossRef]

15. Afkarian, M.; Sedy, J.R.; Yang, J.; Jacobson, N.G.; Cereb, N.; Yang, S.Y.; Murphy, T.L.; Murphy, K.M. T-bet is a STAT1-induced regulator of IL-12R expression in naïve CD4+ T cells. Nat. Immunol. 2002, 3, 549-557. [CrossRef] [PubMed]

16. Nurieva, R.I.; Chung, Y.; Hwang, D.; Yang, X.O.; Kang, H.S.; Ma, L.; Wang, Y.; Watowich, S.S.; Jetten, A.M.; Tian, Q.; et al. Generation of T Follicular Helper Cells Is Mediated by Interleukin-21 but Independent of T Helper 1, 2, or 17 Cell Lineages. Immunity 2008, 29, 138-149. [CrossRef] [PubMed]

17. Diehl, S.A.; Schmidlin, H.; Nagasawa, M.; Blom, B.; Spits, H. IL-6 Triggers IL-21 production by human CD4+ T cells to drive STAT3-dependent plasma cell differentiation in B cells. Immunol. Cell Biol. 2012, 90, 802-811. [CrossRef]

18. Dienz, O.; Eaton, S.M.; Bond, J.P.; Neveu, W.; Moquin, D.; Noubade, R.; Briso, E.M.; Charland, C.; Leonard, W.J.; Ciliberto, G.; et al. The induction of antibody production by IL-6 is indirectly mediated by IL-21 produced by CD4 + T cells. J. Exp. Med. 2009, 206, 69-78. [CrossRef]

19. Di Toro, D.; Winstead, C.J.; Pham, D.; Witte, S.; Andargachew, R.; Singer, J.R.; Wilson, C.G.; Zindl, C.L.; Luther, R.J.; Silberger, D.J.; et al. Differential IL-2 expression defines developmental fates of follicular versus nonfollicular helper T cells. Science 2018, 361, eaao2933. [CrossRef] 
20. Papillion, A.; Powell, M.D.; Chisolm, D.A.; Bachus, H.; Fuller, M.J.; Weinmann, A.S.; Villarino, A.; O’Shea, J.J.; León, B.; Oestreich, K.J.; et al. Inhibition of IL-2 responsiveness by IL-6 is required for the generation of GC-TFH cells. Sci. Immunol. 2019, 4. [CrossRef]

21. Vogelzang, A.; McGuire, H.M.; Yu, D.; Sprent, J.; Mackay, C.R.; King, C. A Fundamental Role for Interleukin-21 in the Generation of T Follicular Helper Cells. Immunity 2008, 29, 127-137. [CrossRef] [PubMed]

22. Nurieva, R.I.; Chung, Y.; Martinez, G.J.; Yang, X.O.; Tanaka, S.; Matskevitch, T.D.; Wang, Y.-H.; Dong, C. Bcl6 mediates the development of T follicular helper cells. Science 2009, 325, 1001-1005. [CrossRef] [PubMed]

23. Szabo, S.J.; Kim, S.T.; Costa, G.L.; Zhang, X.; Fathman, C.G.; Glimcher, L.H. A Novel Transcription Factor, T-bet, Directs Th1 Lineage Commitment. Cell 2000, 100, 655-669. [CrossRef]

24. Qi, H. T follicular helper cells in space-time. Nat. Rev. Immunol. 2016, 16, 612-625. [CrossRef]

25. Nakayamada, S.; Kanno, Y.; Takahashi, H.; Jankovic, D.; Lu, K.T.; Johnson, T.A.; Sun, H.; Vahedi, G.; Hakim, O.; Handon, R.; et al. Early Th1 cell differentiation is marked by a Tfh cell-like transition. Immunity 2011, 35, 919-931. [CrossRef] [PubMed]

26. Oestreich, K.J.; Huang, A.C.; Weinmann, A.S. The lineage-defining factors T-bet and Bcl-6 collaborate to regulate Th1 gene expression patterns. J. Exp. Med. 2011, 208, 1001-1013. [CrossRef]

27. Oestreich, K.J.; Mohn, S.E.; Weinmann, A.S. Molecular mechanisms that control the expression and activity of Bcl-6 in TH1 cells to regulate flexibility with a TFH-like gene profile. Nat. Immunol. 2012, 13, 405-411. [CrossRef]

28. Groom, J.R.; Richmond, J.; Murooka, T.T.; Sorensen, E.W.; Sung, J.H.; Bankert, K.; von Andrian, U.H.; Moon, J.J.; Mempel, T.R.; Luster, A.D. CXCR3 chemokine receptor-ligand interactions in the lymph node optimize CD4+ T helper 1 cell differentiation. Immunity 2012, 37, 1091-1103. [CrossRef]

29. Haynes, N.M.; Allen, C.D.C.; Lesley, R.; Ansel, K.M.; Killeen, N.; Cyster, J.G. Role of CXCR5 and CCR7 in Follicular Th Cell Positioning and Appearance of a Programmed Cell Death Gene-1 High Germinal Center-Associated Subpopulation. J. Immunol. 2007, 179, 5099-5108. [CrossRef]

30. Hardtke, S.; Ohl, L.; Förster, R. Balanced expression of CXCR5 and CCR7 on follicular T helper cells determines their transient positioning to lymph node follicles and is essential for efficient B-cell help. Blood 2005, 106, 1924-1931. [CrossRef]

31. Li, J.; Lu, E.; Yi, T.; Cyster, J.G. EBI2 augments Tfh cell fate by promoting interaction with IL-2-quenching dendritic cells. Nature 2016, 533, 110-114. [CrossRef] [PubMed]

32. Hercor, M.; Anciaux, M.; Denanglaire, S.; Debuisson, D.; Leo, O.; Andris, F. Antigen-presenting cell-derived IL-6 restricts the expression of GATA3 and IL-4 by follicular helper T cells. J. Leukoc. Biol. 2017, 101, 5-14. [CrossRef] [PubMed]

33. Reif, K.; Ekland, E.H.; Ohl, L.; Nakano, H.; Lipp, M.; Förster, R.; Cyster, J.G. Balanced responsiveness to chemoattractants from adjacent zones determines B-cell position. Nature 2002, 416, 94-99. [CrossRef] [PubMed]

34. Xu, H.; Li, X.; Liu, D.; Li, J.; Zhang, X.; Chen, X.; Hou, S.; Peng, L.; Xu, C.; Liu, W.; et al. Follicular T-helper cell recruitment governed by bystander B cells and ICOS-driven motility. Nature 2013, 496, 523-527. [CrossRef]

35. Avancena, P.; Song, T.; Yao, Y.; Fehlner-Peach, H.; Diamond, B.; Gu, H.; Rajewsky, K.; Zou, Y.-R. The magnitude of germinal center reactions is restricted by a fixed number of preexisting niches. Proc. Natl. Acad. Sci. USA 2021, 118, e2100576118. [CrossRef]

36. Heesters, B.A.; Myers, R.C.; Carroll, M.C. Follicular dendritic cells: Dynamic antigen libraries. Nat. Rev. Immunol. 2014, 14, 495-504. [CrossRef]

37. Weber, J.P.; Fuhrmann, F.; Hutloff, A. T-follicular helper cells survive as long-term memory cells. Eur. J. Immunol. 2012, 42, 1981-1988. [CrossRef]

38. Suan, D.; Nguyen, A.; Moran, I.; Bourne, K.; Hermes, J.R.; Arshi, M.; Hampton, H.R.; Tomura, M.; Miwa, Y.; Kelleher, A.D.; et al. T Follicular Helper Cells Have Distinct Modes of Migration and Molecular Signatures in Naive and Memory Immune Responses. Immunity 2015, 42, 704-718. [CrossRef]

39. Asrir, A.; Aloulou, M.; Gador, M.; Pérals, C.; Fazilleau, N. Interconnected subsets of memory follicular helper T cells have different effector functions. Nat. Commun. 2017, 8, 847. [CrossRef]

40. Cyster, J.G.; Allen, C.D.C. B Cell Responses: Cell Interaction Dynamics and Decisions. Cell 2019, 177, 524-540. [CrossRef]

41. Victora, G.D.; Schwickert, T.A.; Fooksman, D.R.; Kamphorst, A.O.; Meyer-Hermann, M.; Dustin, M.L.; Nussenzweig, M.C. Germinal Center Dynamics Revealed by Multiphoton Microscopy with a Photoactivatable Fluorescent Reporter. Cell 2010, 143, 592-605. [CrossRef] [PubMed]

42. Shulman, Z.; Gitlin, A.D.; Weinstein, J.S.; Lainez, B.; Esplugues, E.; Flavell, R.A.; Craft, J.E.; Nussenzweig, M.C. Dynamic signaling by $\mathrm{T}$ follicular helper cells during germinal center B cell selection. Science 2014, 345, 1058-1062. [CrossRef]

43. Gitlin, A.D.; Shulman, Z.; Nussenzweig, M.C. Clonal selection in the germinal centre by regulated proliferation and hypermutation. Nature 2014, 509, 637-640. [CrossRef]

44. Merkenschlager, J.; Finkin, S.; Ramos, V.; Kraft, J.; Cipolla, M.; Nowosad, C.R.; Hartweger, H.; Zhang, W.; Olinares, P.D.B.; Gazumyan, A.; et al. Dynamic regulation of TFH selection during the germinal centre reaction. Nature 2021, 591, 458-463. [CrossRef]

45. Fazilleau, N.; Eisenbraun, M.D.; Malherbe, L.; Ebright, J.N.; Pogue-Caley, R.R.; McHeyzer-Williams, L.J.; McHeyzer-Williams, M.G. Lymphoid reservoirs of antigen-specific memory T helper cells. Nat. Immunol. 2007, 8, 753-761. [CrossRef]

46. Weber, J.P.; Fuhrmann, F.; Feist, R.K.; Lahmann, A.; Al Baz, M.S.; Gentz, L.-J.; Vu Van, D.; Mages, H.W.; Haftmann, C.; Riedel, R.; et al. ICOS maintains the T follicular helper cell phenotype by down-regulating Krüppel-like factor 2. J. Exp. Med. 2015, 212, 217-233. [CrossRef] [PubMed] 
47. Linterman, M.A.; Denton, A.E.; Divekar, D.P.; Zvetkova, I.; Kane, L.; Ferreira, C.; Veldhoen, M.; Clare, S.; Dougan, G.; Espéli, M.; et al. CD28 expression is required after T cell priming for helper $\mathrm{T}$ cell responses and protective immunity to infection. Elife 2014, 3, e03180. [CrossRef] [PubMed]

48. Glatigny, S.; Höllbacher, B.; Motley, S.J.; Tan, C.; Hundhausen, C.; Buckner, J.H.; Smilek, D.; Khoury, S.J.; Ding, L.; Qin, T.; et al. Abatacept Targets T Follicular Helper and Regulatory T Cells, Disrupting Molecular Pathways That Regulate Their Proliferation and Maintenance. J. Immunol. 2019, 202, 1373-1382. [CrossRef] [PubMed]

49. Akiba, H.; Takeda, K.; Kojima, Y.; Usui, Y.; Harada, N.; Yamazaki, T.; Ma, J.; Tezuka, K.; Yagita, H.; Okumura, K. The Role of ICOS in the CXCR5+ Follicular B Helper T Cell Maintenance In Vivo. J. Immunol. 2005, 175, 2340-2348. [CrossRef]

50. Pratama, A.; Srivastava, M.; Williams, N.J.; Papa, I.; Lee, S.K.; Dinh, X.T.; Hutloff, A.; Jordan, M.A.; Zhao, J.L.; Casellas, R.; et al. MicroRNA-146a regulates ICOS-ICOSL signalling to limit accumulation of $\mathrm{T}$ follicular helper cells and germinal centres. Nat. Commun. 2015, 6, 6436. [CrossRef]

51. Liu, D.; Xu, H.; Shih, C.; Wan, Z.; Ma, X.; Ma, W.; Luo, D.; Qi, H. T-B-cell entanglement and ICOSL-driven feed-forward regulation of germinal centre reaction. Nature 2015, 517, 214-218. [CrossRef]

52. Shi, J.; Hou, S.; Fang, Q.; Liu, X.; Liu, X.; Qi, H. PD-1 Controls Follicular T Helper Cell Positioning and Function. Immunity 2018, 49, 264-274.e4. [CrossRef]

53. Jacquemin, C.; Schmitt, N.; Contin-Bordes, C.; Liu, Y.; Narayanan, P.; Seneschal, J.; Maurouard, T.; Dougall, D.; Davizon, E.S.; Dumortier, H.; et al. OX40 Ligand Contributes to Human Lupus Pathogenesis by Promoting T Follicular Helper Response. Immunity 2015, 42, 1159-1170. [CrossRef]

54. Förster, R.; Emrich, T.; Kremmer, E.; Lipp, M. Expression of the G-Protein-Coupled Receptor BLR1 Defines Mature, Recirculating B Cells and a Subset of T-Helper Memory Cells. Blood 1994, 84, 830-840. [CrossRef]

55. He, J.; Tsai, L.M.; Leong, Y.A.; Hu, X.; Ma, C.S.; Chevalier, N.; Sun, X.; Vandenberg, K.; Rockman, S.; Ding, Y.; et al. Circulating Precursor CCR7loPD-1hi CXCR5+ CD4+ T Cells Indicate Tfh Cell Activity and Promote Antibody Responses upon Antigen Reexposure. Immunity 2013, 39, 770-781. [CrossRef] [PubMed]

56. Locci, M.; Havenar-Daughton, C.; Landais, E.; Wu, J.; Kroenke, M.A.; Arlehamn, C.L.; Su, L.F.; Cubas, R.; Davis, M.M.; Sette, A.; et al. Human circulating PD-1+CXCR3-CXCR5+ memory Tfh cells are highly functional and correlate with broadly neutralizing HIV antibody responses. Immunity 2013, 39, 758-769. [CrossRef]

57. Lüthje, K.; Kallies, A.; Shimohakamada, Y.; Belz, G.T.; Light, A.; Tarlinton, D.M.; Nutt, S.L. The development and fate of follicular helper T cells defined by an IL-21 reporter mouse. Nat. Immunol. 2012, 13, 491-498. [CrossRef] [PubMed]

58. Bossaller, L.; Burger, J.; Draeger, R.; Grimbacher, B.; Knoth, R.; Plebani, A.; Durandy, A.; Baumann, U.; Schlesier, M.; Welcher, A.A.; et al. ICOS Deficiency Is Associated with a Severe Reduction of CXCR5+ CD4 Germinal Center Th Cells. J. Immunol. 2006, 177, 4927-4932. [CrossRef] [PubMed]

59. Ma, C.S.; Avery, D.T.; Chan, A.; Batten, M.; Bustamante, J.; Boisson-Dupuis, S.; Arkwright, P.D.; Kreins, A.Y.; Averbuch, D.; Engelhard, D.; et al. Functional STAT3 deficiency compromises the generation of human T follicular helper cells. Blood 2012, 119, 3997-4008. [CrossRef] [PubMed]

60. Cicalese, M.P.; Gerosa, J.; Baronio, M.; Montin, D.; Licciardi, F.; Soresina, A.; Dellepiane, R.M.; Miano, M.; Baselli, L.A.; Volpi, S.; et al. Circulating follicular helper and follicular regulatory T cells are severely compromised in human CD40 deficiency: A case report. Front. Immunol. 2018, 9, 1761. [CrossRef] [PubMed]

61. Martini, H.; Enright, V.; Perro, M.; Workman, S.; Birmelin, J.; Giorda, E.; Quinti, I.; Lougaris, V.; Baronio, M.; Warnatz, K.; et al. Importance of B cell co-stimulation in CD4(+) T cell differentiation: X-linked agammaglobulinaemia, a human model. Clin. Exp. Immunol. 2011, 164, 381-387. [CrossRef]

62. Brenna, E.; Davydov, A.N.; Ladell, K.; McLaren, J.E.; Bonaiuti, P.; Metsger, M.; Ramsden, J.D.; Gilbert, S.C.; Lambe, T.; Price, D.A.; et al. CD4+ T Follicular Helper Cells in Human Tonsils and Blood Are Clonally Convergent but Divergent from Non-Tfh CD4+ Cells. Cell Rep. 2020, 30, 137-152.e5. [CrossRef] [PubMed]

63. Vella, L.A.; Buggert, M.; Manne, S.; Herati, R.S.; Sayin, I.; Kuri-Cervantes, L.; Bukh Brody, I.; O’Boyle, K.C.; Kaprielian, H.; Giles, J.R.; et al. T follicular helper cells in human efferent lymph retain lymphoid characteristics. J. Clin. Investig. 2019, 129, 3185-3200. [CrossRef] [PubMed]

64. Herati, R.S.; Muselman, A.; Vella, L.; Bengsch, B.; Parkhouse, K.; Del Alcazar, D.; Kotzin, J.; Doyle, S.A.; Tebas, P.; Hensley, S.E.; et al. Successive annual influenza vaccination induces a recurrent oligoclonotypic memory response in circulating T follicular helper cells. Sci. Immunol. 2017, 2, eaag2152. [CrossRef] [PubMed]

65. Morita, R.; Schmitt, N.; Bentebibel, S.-E.; Ranganathan, R.; Bourdery, L.; Zurawski, G.; Foucat, E.; Dullaers, M.; Oh, S.; Sabzghabaei, N.; et al. Human blood CXCR5(+)CD4(+) T cells are counterparts of T follicular cells and contain specific subsets that differentially support antibody secretion. Immunity 2011, 34, 108-121. [CrossRef] [PubMed]

66. Obeng-Adjei, N.; Portugal, S.; Tran, T.M.; Yazew, T.B.; Skinner, J.; Li, S.; Jain, A.; Felgner, P.L.; Doumbo, O.K.; Kayentao, K.; et al. Circulating Th1-Cell-type Tfh Cells that Exhibit Impaired B Cell Help Are Preferentially Activated during Acute Malaria in Children. Cell Rep. 2015, 13, 425-439. [CrossRef] [PubMed]

67. Bentebibel, S.-E.; Lopez, S.; Obermoser, G.; Schmitt, N.; Mueller, C.; Harrod, C.; Flano, E.; Mejias, A.; Albrecht, R.A.; Blankenship, D.; et al. Induction of ICOS+CXCR3+CXCR5+ TH cells correlates with antibody responses to influenza vaccination. Sci. Transl. Med. 2013, 5, 176ra32. [CrossRef] [PubMed] 
68. Koutsakos, M.; Wheatley, A.K.; Loh, L.; Clemens, E.B.; Sant, S.; Nüssing, S.; Fox, A.; Chung, A.W.; Laurie, K.L.; Hurt, A.C.; et al. Circulating Tfh cells, serological memory, and tissue compartmentalization shape human influenza-specific B cell immunity. Sci. Transl. Med. 2018, 10, eaan8405. [CrossRef]

69. Zhang, J.; Liu, W.; Wen, B.; Xie, T.; Tang, P.; Hu, Y.; Huang, L.; Jin, K.; Zhang, P.; Liu, Z.; et al. Circulating CXCR3(+) Tfh cells positively correlate with neutralizing antibody responses in HCV-infected patients. Sci. Rep. 2019, 9, 10090. [CrossRef]

70. Lee, S.K.; Silva, D.G.; Martin, J.L.; Pratama, A.; Hu, X.; Chang, P.-P.; Walters, G.; Vinuesa, C.G. Interferon-y Excess Leads to Pathogenic Accumulation of Follicular Helper T Cells and Germinal Centers. Immunity 2012, 37, 880-892. [CrossRef]

71. Reinhardt, R.L.; Liang, H.-E.; Locksley, R.M. Cytokine-secreting follicular T cells shape the antibody repertoire. Nat. Immunol. 2009, 10, 385-393. [CrossRef]

72. Fang, D.; Cui, K.; Mao, K.; Hu, G.; Li, R.; Zheng, M.; Riteau, N.; Reiner, S.L.; Sher, A.; Zhao, K.; et al. Transient T-bet expression functionally specifies a distinct $\mathrm{T}$ follicular helper subset. J. Exp. Med. 2018, 215, 2705-2714. [CrossRef]

73. Weinstein, J.S.; Laidlaw, B.J.; Lu, Y.; Wang, J.K.; Schulz, V.P.; Li, N.; Herman, E.I.; Kaech, S.M.; Gallagher, P.G.; Craft, J. STAT4 and T-bet control follicular helper T cell development in viral infections. J. Exp. Med. 2017, 215, 337-355. [CrossRef]

74. Heit, A.; Schmitz, F.; Gerdts, S.; Flach, B.; Moore, M.S.; Perkins, J.A.; Robins, H.S.; Aderem, A.; Spearman, P.; Tomaras, G.D.; et al. Vaccination establishes clonal relatives of germinal center T cells in the blood of humans. J. Exp. Med. 2017, 214, $2139-2152$. [CrossRef]

75. Spensieri, F.; Borgogni, E.; Zedda, L.; Bardelli, M.; Buricchi, F.; Volpini, G.; Fragapane, E.; Tavarini, S.; Finco, O.; Rappuoli, R.; et al. Human circulating influenza-CD4+ ICOS1+IL-21+ T cells expand after vaccination, exert helper function, and predict antibody responses. Proc. Natl. Acad. Sci. USA 2013, 110, 14330-14335. [CrossRef]

76. Schultz, B.T.; Teigler, J.E.; Pissani, F.; Oster, A.F.; Kranias, G.; Alter, G.; Marovich, M.; Eller, M.A.; Dittmer, U.; Robb, M.L.; et al. Circulating HIV-Specific Interleukin-21+CD4+T Cells Represent Peripheral Tfh Cells with Antigen-Dependent Helper Functions. Immunity 2016, 44, 167-178. [CrossRef]

77. Boswell, K.L.; Paris, R.; Boritz, E.; Ambrozak, D.; Yamamoto, T.; Darko, S.; Wloka, K.; Wheatley, A.; Narpala, S.; McDermott, A.; et al. Loss of circulating CD4 T cells with B cell helper function during chronic HIV infection. PLoS Pathog. 2014, 10, e1003853. [CrossRef]

78. Simpson, N.; Gatenby, P.A.; Wilson, A.; Malik, S.; Fulcher, D.A.; Tangye, S.G.; Manku, H.; Vyse, T.J.; Roncador, G.; Huttley, G.A.; et al. Expansion of circulating T cells resembling follicular helper T cells is a fixed phenotype that identifies a subset of severe systemic lupus erythematosus. Arthritis Rheum. 2010, 62, 234-244. [CrossRef]

79. Moyron-Quiroz, J.E.; Rangel-Moreno, J.; Kusser, K.; Hartson, L.; Sprague, F.; Goodrich, S.; Woodland, D.L.; Lund, F.E.; Randall, T.D. Role of inducible bronchus associated lymphoid tissue (iBALT) in respiratory immunity. Nat. Med. 2004, 10, 927-934. [CrossRef]

80. Fleige, H.; Ravens, S.; Moschovakis, G.L.; Bölter, J.; Willenzon, S.; Sutter, G.; Häussler, S.; Kalinke, U.; Prinz, I.; Förster, R. IL-17-induced CXCL12 recruits B cells and induces follicle formation in BALT in the absence of differentiated FDCs. J. Exp. Med. 2014, 211, 643-651. [CrossRef]

81. Ferreira-Gomes, M.; Kruglov, A.; Durek, P.; Heinrich, F.; Tizian, C.; Heinz, G.A.; Pascual-Reguant, A.; Du, W.; Mothes, R.; Fan, C.; et al. SARS-CoV-2 in severe COVID-19 induces a TGF- $\beta$-dominated chronic immune response that does not target itself. Nat. Commun. 2021, 12, 1961. [CrossRef]

82. Rendeiro, A.F.; Ravichandran, H.; Bram, Y.; Chandar, V.; Kim, J.; Meydan, C.; Park, J.; Foox, J.; Hether, T.; Warren, S.; et al. The spatial landscape of lung pathology during COVID-19 progression. Nature 2021, 593, 564-569. [CrossRef]

83. Ramos da Silva, S.; Ju, E.; Meng, W.; Paniz Mondolfi, A.E.; Dacic, S.; Green, A.; Bryce, C.; Grimes, Z.; Fowkes, M.; Sordillo, E.M.; et al. Broad Severe Acute Respiratory Syndrome Coronavirus 2 Cell Tropism and Immunopathology in Lung Tissues From Fatal Coronavirus Disease 2019. J. Infect. Dis. 2021, 223, 1842-1854. [CrossRef]

84. Dorward, D.A.; Russell, C.D.; Um, I.H.; Elshani, M.; Armstrong, S.D.; Penrice-Randal, R.; Millar, T.; Lerpiniere, C.E.B.; Tagliavini, G.; Hartley, C.S.; et al. Tissue-Specific Immunopathology in Fatal COVID-19. Am. J. Respir. Crit. Care Med. 2020, $203,192-201$. [CrossRef]

85. Hutloff, A. T Follicular Helper-Like Cells in In amed Non-Lymphoid Tissues. Front. Immunol. 2018, 9, 1707. [CrossRef] [PubMed]

86. Vu Van, D.; Beier, K.C.; Pietzke, L.-J.; Al Baz, M.S.; Feist, R.K.; Gurka, S.; Hamelmann, E.; Kroczek, R.A.; Hutloff, A. Local T/B cooperation in inflamed tissues is supported by T follicular helper-like cells. Nat. Commun. 2016, 7, 10875. [CrossRef] [PubMed]

87. Vu Van, D.; Bauer, L.; Kroczek, R.A.; Hutloff, A. ICOS Costimulation Differentially Affects T Cells in Secondary Lymphoid Organs and Inflamed Tissues. Am. J. Respir. Cell. Mol. Biol. 2018, 59, 437-447. [CrossRef] [PubMed]

88. Rao, D.A.; Gurish, M.F.; Marshall, J.L.; Slowikowski, K.; Fonseka, C.Y.; Liu, Y.; Donlin, L.T.; Henderson, L.A.; Wei, K.; Mizoguchi, F.; et al. Pathologically expanded peripheral T helper cell subset drives B cells in rheumatoid arthritis. Nature 2017, 542, 110-114. [CrossRef] [PubMed]

89. Bocharnikov, A.V.; Keegan, J.; Wacleche, V.S.; Cao, Y.; Fonseka, C.Y.; Wang, G.; Muise, E.S.; Zhang, K.X.; Arazi, A.; Keras, G.; et al. PD-1hiCXCR5- T peripheral helper cells promote B cell responses in lupus via MAF and IL-21. JCI Insight 2019,4 , e130062. [CrossRef]

90. Taylor, D.K.; Mittereder, N.; Kuta, E.; Delaney, T.; Burwell, T.; Dacosta, K.; Zhao, W.; Cheng, L.I.; Brown, C.; Boutrin, A.; et al. T follicular helper-like cells contribute to skin fibrosis. Sci. Transl. Med. 2018, 10, eaaf5307. [CrossRef] 
91. Christophersen, A.; Lund, E.G.; Snir, O.; Solà, E.; Kanduri, C.; Dahal-Koirala, S.; Zühlke, S.; Molberg, Ø.; Utz, P.J.; RohaniPichavant, M.; et al. Distinct phenotype of CD4(+) T cells driving celiac disease identified in multiple autoimmune conditions. Nat. Med. 2019, 25, 734-737. [CrossRef] [PubMed]

92. Zou, Y.; Yuan, H.; Zhou, S.; Zhou, Y.; Zheng, J.; Zhu, H.; Pan, M. The Pathogenic Role of CD4+ Tissue-Resident Memory T Cells Bearing T Follicular Helper-Like Phenotype in Pemphigus Lesions. J. Investig. Dermatol. 2021, 141, 2141-2150. [CrossRef] [PubMed]

93. Wang, H.; Hu, D.-Q.; Xiao, Q.; Liu, Y.-B.; Song, J.; Liang, Y.; Ruan, J.-W.; Wang, Z.-Z.; Li, J.-X.; Pan, L.; et al. Defective STING expression potentiates IL-13 signaling in epithelial cells in eosinophilic chronic rhinosinusitis with nasal polyps. J. Allergy Clin. Immunol. 2021, 147, 1692-1703. [CrossRef] [PubMed]

94. Blokland, S.L.M.; Hillen, M.R.; Kruize, A.A.; Meller, S.; Homey, B.; Smithson, G.M.; Radstake, T.R.D.J.; van Roon, J.A.G. Increased CCL25 and T Helper Cells Expressing CCR9 in the Salivary Glands of Patients With Primary Sjögren's Syndrome: Potential New Axis in Lymphoid Neogenesis. Arthritis Rheumatol. 2017, 69, 2038-2051. [CrossRef]

95. Pontarini, E.; Murray-Brown, W.J.; Croia, C.; Lucchesi, D.; Conway, J.; Rivellese, F.; Fossati-Jimack, L.; Astorri, E.; Prediletto, E.; Corsiero, E.; et al. Unique expansion of IL-21+ Tfh and Tph cells under control of ICOS identifies Sjögren's syndrome with ectopic germinal centres and MALT lymphoma. Ann. Rheum. Dis. 2020, 79, 1588-1599. [CrossRef]

96. Bauer, L.; Müller, L.J.; Volkers, S.M.; Heinrich, F.; Mashreghi, M.F.; Ruppert, C.; Sander, L.E.; Hutloff, A. Follicular helper-like T cells in the lung highlight a novel role of B cells in sarcoidosis. Am. J. Respir. Crit. Care. Med. 2021. [CrossRef]

97. Gu-Trantien, C.; Migliori, E.; Buisseret, L.; de Wind, A.; Brohée, S.; Garaud, S.; Noël, G.; Dang Chi, V.L.; Lodewyckx, J.-N.; Naveaux, C.; et al. CXCL13-producing TFH cells link immune suppression and adaptive memory in human breast cancer. JCI Insight 2017, 2, e91487. [CrossRef]

98. Masopust, D.; Soerens, A.G. Tissue-Resident T Cells and Other Resident Leukocytes. Annu. Rev. Immunol. 2019, 37, 521-546. [CrossRef]

99. Hogan, R.J.; Zhong, W.; Usherwood, E.J.; Cookenham, T.; Roberts, A.D.; Woodland, D.L. Protection from Respiratory Virus Infections Can Be Mediated by Antigen-Specific Cd4+ T Cells that Persist in the Lungs. J. Exp. Med. 2001, 193, 981-986. [CrossRef]

100. Bingaman, A.W.; Patke, D.S.; Mane, V.R.; Ahmadzadeh, M.; Ndejembi, M.; Bartlett, S.T.; Farber, D.L. Novel phenotypes and migratory properties distinguish memory CD4 T cell subsets in lymphoid and lung tissue. Eur. J. Immunol. 2005, 35, 3173-3186. [CrossRef]

101. Oja, A.E.; Piet, B.; Helbig, C.; Stark, R.; van der Zwan, D.; Blaauwgeers, H.; Remmerswaal, E.B.M.; Amsen, D.; Jonkers, R.E.; Moerland, P.D.; et al. Trigger-happy resident memory CD4+ T cells inhabit the human lungs. Mucosal Immunol. 2018, 11, 654-667. [CrossRef]

102. Thome, J.J.C.; Yudanin, N.; Ohmura, Y.; Kubota, M.; Grinshpun, B.; Sathaliyawala, T.; Kato, T.; Lerner, H.; Shen, Y.; Farber, D.L. Spatial Map of Human T Cell Compartmentalization and Maintenance over Decades of Life. Cell 2014, 159, 814-828. [CrossRef] [PubMed]

103. Wong, M.T.; Ong, D.E.H.; Lim, F.S.H.; Teng, K.W.W.; McGovern, N.; Narayanan, S.; Ho, W.Q.; Cerny, D.; Tan, H.K.K.; Anicete, R.; et al. A High-Dimensional Atlas of Human T Cell Diversity Reveals Tissue-Specific Trafficking and Cytokine Signatures. Immunity 2016, 45, 442-456. [CrossRef] [PubMed]

104. GeurtsvanKessel, C.H.; Willart, M.A.M.; Bergen, I.M.; van Rijt, L.S.; Muskens, F.; Elewaut, D.; Osterhaus, A.D.M.E.; Hendriks, R.; Rimmelzwaan, G.F.; Lambrecht, B.N. Dendritic cells are crucial for maintenance of tertiary lymphoid structures in the lung of influenza virus-infected mice. J. Exp. Med. 2009, 206, 2339-2349. [CrossRef] [PubMed]

105. Son, Y.; Cheon, I.; Wu, Y.; Li, C.; Wang, Z.; Gao, X.; Chen, Y.; Takahashi, Y.; Fu, Y.; Dent, A.; et al. Tissue-resident CD4+ T helper cells assist the development of protective respiratory B and CD8+ T cell memory responses. Sci. Immunol. 2021, 6, eabb6852. [CrossRef]

106. Swarnalekha, N.; Schreiner, D.; Litzler, L.C.; Iftikhar, S.; Kirchmeier, D.; Künzli, M.; Son, Y.M.; Sun, J.; Moreira, E.A.; King, C.G. T resident helper cells promote humoral responses in the lung. Sci. Immunol. 2021, 6, eabb6808.

107. Teijaro John, R.; Verhoeven, D.; Carly, P.A.; Turner, D.; Farber, D.L. Memory CD4 T Cells Direct Protective Responses to Influenza Virus in the Lungs through Helper-Independent Mechanisms. J. Virol. 2010, 84, 9217-9226. [CrossRef]

108. Teijaro, J.R.; Turner, D.; Pham, Q.; Wherry, E.J.; Lefrançois, L.; Farber, D.L. Cutting Edge: Tissue-Retentive Lung Memory CD4 T Cells Mediate Optimal Protection to Respiratory Virus Infection. J. Immunol. 2011, 187, 5510-5514. [CrossRef]

109. Allie, S.R.; Bradley, J.E.; Mudunuru, U.; Schultz, M.D.; Graf, B.A.; Lund, F.E.; Randall, T.D. The establishment of resident memory $\mathrm{B}$ cells in the lung requires local antigen encounter. Nat. Immunol. 2019, 20, 97-108. [CrossRef]

110. Joo, H.M.; He, Y.; Sangster, M.Y. Broad dispersion and lung localization of virus-specific memory B cells induced by influenza pneumonia. Proc. Natl. Acad. Sci. USA 2008, 105, 3485-3490. [CrossRef]

111. Onodera, T.; Takahashi, Y.; Yokoi, Y.; Ato, M.; Kodama, Y.; Hachimura, S.; Kurosaki, T.; Kobayashi, K. Memory B cells in the lung participate in protective humoral immune responses to pulmonary influenza virus reinfection. Proc. Natl. Acad. Sci. USA 2012, 109, 2485-2490. [CrossRef]

112. Sakai, S.; Kauffman, K.D.; Schenkel, J.M.; McBerry, C.C.; Mayer-Barber, K.D.; Masopust, D.; Barber, D.L. Cutting Edge: Control of Mycobacterium tuberculosis Infection by a Subset of Lung Parenchyma-Homing CD4 T Cells. J. Immunol. 2014, 192, 2965-2969. [CrossRef] [PubMed] 
113. Zhao, J.; Zhao, J.; Mangalam, A.K.; Channappanavar, R.; Fett, C.; Meyerholz, D.K.; Agnihothram, S.; Baric, R.S.; David, C.S.; Perlman, S. Airway Memory CD4+ T Cells Mediate Protective Immunity against Emerging Respiratory Coronaviruses. Immunity 2016, 44, 1379-1391. [CrossRef]

114. Barker, K.A.; Etesami, N.S.; Shenoy, A.T.; Arafa, E.I.; Lyon de Ana, C.; Smith, N.M.S.; Martin, I.M.C.; Goltry, W.N.; Barron, A.M.S.; Browning, J.L.; et al. Lung-resident memory B cells protect against bacterial pneumonia. J. Clin. Investig. 2021, 131, e141810. [CrossRef] [PubMed]

115. Miyauchi, K.; Sugimoto-Ishige, A.; Harada, Y.; Adachi, Y.; Usami, Y.; Kaji, T.; Inoue, K.; Hasegawa, H.; Watanabe, T.; Hijikata, A.; et al. Protective neutralizing influenza antibody response in the absence of T follicular helper cells. Nat. Immunol. 2016, 17, 1447-1458. [CrossRef] [PubMed]

116. Coffman, R.L.; Sher, A.; Seder, R.A. Vaccine adjuvants: Putting innate immunity to work. Immunity 2010, 33, 492-503. [CrossRef]

117. Ho, N.I.; Huis In 't Veld, L.G.M.; Raaijmakers, T.K.; Adema, G.J. Adjuvants Enhancing Cross-Presentation by Dendritic Cells: The Key to More Effective Vaccines? Front. Immunol. 2018, 9, 2874. [CrossRef]

118. Steinman, R.M.; Banchereau, J. Taking dendritic cells into medicine. Nature 2007, 449, 419-426. [CrossRef]

119. Choi, Y.S.; Eto, D.; Yang, J.A.; Lao, C.; Crotty, S. Cutting Edge: STAT1 Is Required for IL-6-Mediated Bcl6 Induction for Early Follicular Helper Cell Differentiation. J. Immunol. 2013, 190, 3049-3053. [CrossRef]

120. Krishnaswamy, J.K.; Alsén, S.; Yrlid, U.; Eisenbarth, S.C.; Williams, A. Determination of T Follicular Helper Cell Fate by Dendritic Cells. Front. Immunol. 2018, 9, 2169. [CrossRef]

121. Bonam, S.R.; Partidos, C.D.; Halmuthur, S.K.M.; Muller, S. An Overview of Novel Adjuvants Designed for Improving Vaccine Efficacy. Trends Pharmacol. Sci. 2017, 38, 771-793. [CrossRef]

122. Baumjohann, D.; Preite, S.; Reboldi, A.; Ronchi, F.; Ansel, K.M.; Lanzavecchia, A.; Sallusto, F. Persistent Antigen and Germinal Center B Cells Sustain T Follicular Helper Cell Responses and Phenotype. Immunity 2013, 38, 596-605. [CrossRef]

123. Deenick, E.K.; Chan, A.; Ma, C.S.; Gatto, D.; Schwartzberg, P.L.; Brink, R.; Tangye, S.G. Follicular Helper T Cell Differentiation Requires Continuous Antigen Presentation that Is Independent of Unique B Cell Signaling. Immunity 2010, 33, 241-253. [CrossRef] [PubMed]

124. Riteau, N.; Radtke, A.J.; Shenderov, K.; Mittereder, L.; Oland, S.D.; Hieny, S.; Jankovic, D.; Sher, A. Water-in-Oil-Only Adjuvants Selectively Promote T Follicular Helper Cell Polarization through a Type I IFN and IL-6-Dependent Pathway. J. Immunol. 2016, 197, 3884-3893. [CrossRef]

125. Lahmann, A.; Bauer, L.; Hutloff, A. Identification of Follicular T-Cell Subsets in Murine and Human Tissues. Methods Mol. Biol. 2021, 2285, 77-90. [CrossRef] [PubMed]

126. Tam, H.H.; Melo, M.B.; Kang, M.; Pelet, J.M.; Ruda, V.M.; Foley, M.H.; Hu, J.K.; Kumari, S.; Crampton, J.; Baldeon, A.D.; et al. Sustained antigen availability during germinal center initiation enhances antibody responses to vaccination. Proc. Natl. Acad. Sci. USA 2016, 113, E6639-E6648. [CrossRef] [PubMed]

127. Garçon, N.; Di Pasquale, A. From discovery to licensure, the Adjuvant System story. Hum. Vaccin. Immunother. 2017, 13, 19-33. [CrossRef] [PubMed]

128. Hill, D.L.; Pierson, W.; Bolland, D.J.; Mkindi, C.; Carr, E.J.; Wang, J.; Houard, S.; Wingett, S.W.; Audran, R.; Wallin, E.F.; et al. The adjuvant GLA-SE promotes human Tfh cell expansion and emergence of public TCR $\beta$ clonotypes. J. Exp. Med. 2019, 216, 1857-1873. [CrossRef] [PubMed]

129. Nguyen-Contant, P.; Sangster, M.Y.; Topham, D.J. Squalene-Based Influenza Vaccine Adjuvants and Their Impact on the Hemagglutinin-Specific B Cell Response. Pathogens 2021, 10, 355. [CrossRef] [PubMed]

130. Schijns, V.; Fernández-Tejada, A.; Barjaktarović, Ž.; Bouzalas, I.; Brimnes, J.; Chernysh, S.; Gizurarson, S.; Gursel, I.; Jakopin, Ž.; Lawrenz, M.; et al. Modulation of immune responses using adjuvants to facilitate therapeutic vaccination. Immunol. Rev. 2020, 296, 169-190. [CrossRef]

131. Glenny, A.T. Insoluble precipitates in diphtheria and tetanus immunization. Br. Med. J. 1930, 2, 244-245. [CrossRef]

132. Kool, M.; Fierens, K.; Lambrecht, B.N. Alum adjuvant: Some of the tricks of the oldest adjuvant. J. Med. Microbiol. 2012, 61, 927-934. [CrossRef]

133. Ghimire, T.R. The mechanisms of action of vaccines containing aluminum adjuvants: An in vitro vs in vivo paradigm. Springerplus 2015, 4, 181. [CrossRef]

134. Liang, F.; Lindgren, G.; Sandgren, K.J.; Thompson, E.A.; Francica, J.R.; Seubert, A.; De Gregorio, E.; Barnett, S.; O’Hagan, D.T.; Sullivan, N.J.; et al. Vaccine priming is restricted to draining lymph nodes and controlled by adjuvant-mediated antigen uptake. Sci. Transl. Med. 2017, 9, eaal2094. [CrossRef] [PubMed]

135. Didierlaurent, A.M.; Morel, S.; Lockman, L.; Giannini, S.L.; Bisteau, M.; Carlsen, H.; Kielland, A.; Vosters, O.; Vanderheyde, N.; Schiavetti, F.; et al. AS04, an Aluminum Salt- and TLR4 Agonist-Based Adjuvant System, Induces a Transient Localized Innate Immune Response Leading to Enhanced Adaptive Immunity. J. Immunol. 2009, 183, 6186-6197. [CrossRef] [PubMed]

136. Giannini, S.L.; Hanon, E.; Moris, P.; Van Mechelen, M.; Morel, S.; Dessy, F.; Fourneau, M.A.; Colau, B.; Suzich, J.; Losonksy, G.; et al. Enhanced humoral and memory B cellular immunity using HPV16/18 L1 VLP vaccine formulated with the MPL/aluminium salt combination (AS04) compared to aluminium salt only. Vaccine 2006, 24, 5937-5949. [CrossRef] [PubMed]

137. Spensieri, F.; Siena, E.; Borgogni, E.; Zedda, L.; Cantisani, R.; Chiappini, N.; Schiavetti, F.; Rosa, D.; Castellino, F.; Montomoli, E.; et al. Early Rise of Blood T Follicular Helper Cell Subsets and Baseline Immunity as Predictors of Persisting Late Functional Antibody Responses to Vaccination in Humans. PLoS ONE 2016, 11, e0157066. [CrossRef] [PubMed] 
138. Mastelic Gavillet, B.; Eberhardt, C.S.; Auderset, F.; Castellino, F.; Seubert, A.; Tregoning, J.S.; Lambert, P.-H.; de Gregorio, E.; Del Giudice, G.; Siegrist, C.-A. MF59 Mediates Its B Cell Adjuvanticity by Promoting T Follicular Helper Cells and Thus Germinal Center Responses in Adult and Early Life. J. Immunol. 2015, 194, 4836-4845. [CrossRef] [PubMed]

139. Givord, C.; Welsby, I.; Detienne, S.; Thomas, S.; Assabban, A.; Lima Silva, V.; Molle, C.; Gineste, R.; Vermeersch, M.; PerezMorga, D.; et al. Activation of the endoplasmic reticulum stress sensor IRE1 $\alpha$ by the vaccine adjuvant AS03 contributes to its immunostimulatory properties. NPJ Vaccines 2018, 3, 20. [CrossRef]

140. Budroni, S.; Buricchi, F.; Cavallone, A.; Bourguignon, P.; Caubet, M.; Dewar, V.; D’Oro, U.; Finco, O.; Garçon, N.; El Idrissi, M.; et al. Antibody avidity, persistence, and response to antigen recall: Comparison of vaccine adjuvants. NPJ Vaccines 2021, 6, 78. [CrossRef]

141. Treanor, J.J.; Essink, B.; Hull, S.; Reed, S.; Izikson, R.; Patriarca, P.; Goldenthal, K.L.; Kohberger, R.; Dunkle, L.M. Evaluation of safety and immunogenicity of recombinant influenza hemagglutinin (H5/Indonesia/05/2005) formulated with and without a stable oil-in-water emulsion containing glucopyranosyl-lipid A (SE+GLA) adjuvant. Vaccine 2013, 31, 5760-5765. [CrossRef]

142. Seydoux, E.; Liang, H.; Dubois Cauwelaert, N.; Archer, M.; Rintala, N.D.; Kramer, R.; Carter, D.; Fox, C.B.; Orr, M.T. Effective Combination Adjuvants Engage Both TLR and Inflammasome Pathways To Promote Potent Adaptive Immune Responses. J. Immunol. 2018, 201, 98-112. [CrossRef]

143. Baldwin, S.L.; Roeffen, W.; Singh, S.K.; Tiendrebeogo, R.W.; Christiansen, M.; Beebe, E.; Carter, D.; Fox, C.B.; Howard, R.F.; Reed, S.G.; et al. Synthetic TLR4 agonists enhance functional antibodies and CD4+ T-cell responses against the Plasmodium falciparum GMZ2.6C multi-stage vaccine antigen. Vaccine 2016, 34, 2207-2215. [CrossRef]

144. Van Hoeven, N.; Joshi, S.W.; Nana, G.I.; Bosco-Lauth, A.; Fox, C.; Bowen, R.A.; Clements, D.E.; Martyak, T.; Parks, D.E.; Baldwin, S.; et al. A Novel Synthetic TLR-4 Agonist Adjuvant Increases the Protective Response to a Clinical-Stage West Nile Virus Vaccine Antigen in Multiple Formulations. PLoS ONE 2016, 11, e0149610.

145. Leroux-Roels, I.; Devaster, J.-M.; Leroux-Roels, G.; Verlant, V.; Henckaerts, I.; Moris, P.; Hermand, P.; Van Belle, P.; Poolman, J.T.; Vandepapelière, P.; et al. Adjuvant system AS02V enhances humoral and cellular immune responses to pneumococcal protein PhtD vaccine in healthy young and older adults: Randomised, controlled trials. Vaccine 2015, 33, 577-584. [CrossRef] [PubMed]

146. Leroux-Roels, G.; Marchant, A.; Levy, J.; Van Damme, P.; Schwarz, T.F.; Horsmans, Y.; Jilg, W.; Kremsner, P.G.; Haelterman, E.; Clément, F.; et al. Impact of adjuvants on CD4+ T cell and B cell responses to a protein antigen vaccine: Results from a phase II, randomized, multicenter trial. Clin. Immunol. 2016, 169, 16-27. [CrossRef]

147. Nielsen, C.M.; Ogbe, A.; Pedroza-Pacheco, I.; Doeleman, S.E.; Chen, Y.; Silk, S.E.; Barrett, J.R.; Elias, S.C.; Miura, K.; Diouf, A.; et al. Protein/AS01B vaccination elicits stronger, more Th2-skewed antigen-specific human T follicular helper cell responses than heterologous viral vectors. Cell. Rep. Med. 2021, 2, 100207. [CrossRef]

148. Aljurayyan, A.N.; Sharma, R.; Upile, N.; Beer, H.; Vaughan, C.; Xie, C.; Achar, P.; Ahmed, M.S.; McNamara, P.S.; Gordon, S.B.; et al. A critical role of $\mathrm{T}$ follicular helper cells in human mucosal anti-influenza response that can be enhanced by immunological adjuvant CpG-DNA. Antivir. Res. 2016, 132, 122-130. [CrossRef] [PubMed]

149. Claassen, E.; de Leeuw, W.; de Greeve, P.; Hendriksen, C.; Boersma, W. Freund's complete adjuvant: An effective but disagreeable formula. Res. Immunol. 1992, 143, 478-483. [CrossRef]

150. Chakarov, S.; Fazilleau, N. Monocyte-derived dendritic cells promote T follicular helper cell differentiation. EMBO Mol. Med. 2014, 6, 590-603. [CrossRef] [PubMed]

151. van Doorn, E.; Liu, H.; Huckriede, A.; Hak, E. Safety and tolerability evaluation of the use of Montanide ISA $^{\mathrm{TM}} 51$ as vaccine adjuvant: A systematic review. Hum. Vaccines Immunother. 2016, 12, 159-169. [CrossRef] [PubMed]

152. Wang, Z.-B.; Xu, J. Better Adjuvants for Better Vaccines: Progress in Adjuvant Delivery Systems, Modifications, and AdjuvantAntigen Codelivery. Vaccines 2020, 8, 128. [CrossRef] [PubMed]

153. Lu, L.; Fong, C.H.-Y.; Zhang, A.J.; Wu, W.-L.; Li, I.C.; Lee, A.C.-Y.; Dissanayake, T.K.; Chen, L.; Hung, I.F.-N.; Chan, K.-H.; et al. Repurposing of Miltefosine as an Adjuvant for Influenza Vaccine. Vaccines 2020, 8, 754. [CrossRef] [PubMed]

154. Mukherjee, A.K.; Gupta, G.; Adhikari, A.; Majumder, S.; Kar Mahapatra, S.; Bhattacharyya Majumdar, S.; Majumdar, S. Miltefosine triggers a strong proinflammatory cytokine response during visceral leishmaniasis: Role of TLR4 and TLR9. Int. Immunopharmacol. 2012, 12, 565-572. [CrossRef]

155. Gibson, S.J.; Lindh, J.M.; Riter, T.R.; Gleason, R.M.; Rogers, L.M.; Fuller, A.E.; Oesterich, J.L.; Gorden, K.B.; Qiu, X.; McKane, S.W.; et al. Plasmacytoid dendritic cells produce cytokines and mature in response to the TLR7 agonists, imiquimod and resiquimod. Cell. Immunol. 2002, 218, 74-86. [CrossRef]

156. Kasturi, S.P.; Rasheed, M.A.U.; Havenar-Daughton, C.; Pham, M.; Legere, T.; Sher, Z.J.; Kovalenkov, Y.; Gumber, S.; Huang, J.Y.; Gottardo, R.; et al. 3M-052, a synthetic TLR-7/8 agonist, induces durable HIV-1 envelope-specific plasma cells and humoral immunity in nonhuman primates. Sci. Immunol. 2020, 5, eabb1025. [CrossRef] [PubMed]

157. Kuo, T.-Y.; Lin, M.-Y.; Coffman, R.L.; Campbell, J.D.; Traquina, P.; Lin, Y.-J.; Liu, L.T.-C.; Cheng, J.; Wu, Y.-C.; Wu, C.-C.; et al. Development of CpG-adjuvanted stable prefusion SARS-CoV-2 spike antigen as a subunit vaccine against COVID-19. Sci. Rep. 2020, 10, 20085. [CrossRef]

158. Vono, M.; Eberhardt, C.S.; Mohr, E.; Auderset, F.; Christensen, D.; Schmolke, M.; Coler, R.; Meinke, A.; Andersen, P.; Lambert, P.-H.; et al. Overcoming the Neonatal Limitations of Inducing Germinal Centers through Liposome-Based Adjuvants Including C-Type Lectin Agonists Trehalose Dibehenate or Curdlan. Front. Immunol. 2018, 9, 381. [CrossRef] 
159. van Dissel, J.T.; Soonawala, D.; Joosten, S.A.; Prins, C.; Arend, S.M.; Bang, P.; Tingskov, P.N.; Lingnau, K.; Nouta, J.; Hoff, S.T.; et al. Ag85B-ESAT-6 adjuvanted with IC $31{ }^{\circledR}$ promotes strong and long-lived Mycobacterium tuberculosis specific T cell responses in volunteers with previous BCG vaccination or tuberculosis infection. Vaccine 2011, 29, 2100-2109. [CrossRef]

160. Knudsen, N.P.H.; Olsen, A.; Buonsanti, C.; Follmann, F.; Zhang, Y.; Coler, R.N.; Fox, C.B.; Meinke, A.; D’Oro, U.; Casini, D.; et al. Different human vaccine adjuvants promote distinct antigen-independent immunological signatures tailored to different pathogens. Sci. Rep. 2016, 6, 19570. [CrossRef]

161. Lirussi, D.; Weissmann, S.F.; Ebensen, T.; Nitsche-Gloy, U.; Franz, H.B.G.; Guzmán, C.A. Cyclic Di-Adenosine Monophosphate: A Promising Adjuvant Candidate for the Development of Neonatal Vaccines. Pharmaceutics 2021, 13, 188. [CrossRef]

162. Chauveau, L.; Bridgeman, A.; Tan, T.K.; Beveridge, R.; Frost, J.N.; Rijal, P.; Pedroza-Pacheco, I.; Partridge, T.; Gilbert-Jaramillo, J.; Knight, M.L.; et al. Inclusion of cGAMP within virus-like particle vaccines enhances their immunogenicity. EMBO Rep. 2021, 22, e52447. [CrossRef] [PubMed]

163. Carnathan, D.G.; Kaushik, K.; Ellebedy, A.H.; Enemuo, C.A.; Gebru, E.H.; Dhadvai, P.; Rasheed, M.A.U.; Pauthner, M.G.; Ozorowski, G.; Ahmed, R.; et al. Harnessing Activin A Adjuvanticity to Promote Antibody Responses to BG505 HIV Envelope Trimers. Front. Immunol. 2020, 11, 1213. [CrossRef] [PubMed]

164. Agren, L.C.; Ekman, L.; Löwenadler, B.; Lycke, N.Y. Genetically engineered nontoxic vaccine adjuvant that combines B cell targeting with immunomodulation by cholera toxin A1 subunit. J. Immunol. 1997, 158, 3936-3946. [PubMed]

165. Eriksson, A.M.; Schön, K.M.; Lycke, N.Y. The Cholera Toxin-Derived CTA1-DD Vaccine Adjuvant Administered Intranasally Does Not Cause Inflammation or Accumulate in the Nervous Tissues. J. Immunol. 2004, 173, 3310-3319. [CrossRef] [PubMed]

166. Bemark, M.; Bergqvist, P.; Stensson, A.; Holmberg, A.; Mattsson, J.; Lycke, N.Y. A Unique Role of the Cholera Toxin A1-DD Adjuvant for Long-Term Plasma and Memory B Cell Development. J. Immunol. 2011, 186, 1399-1410. [CrossRef] [PubMed]

167. Schussek, S.; Bernasconi, V.; Mattsson, J.; Wenzel, U.A.; Strömberg, A.; Gribonika, I.; Schön, K.; Lycke, N.Y. The CTA1-DD adjuvant strongly potentiates follicular dendritic cell function and germinal center formation, which results in improved neonatal immunization. Mucosal Immunol. 2020, 13, 545-557. [CrossRef]

168. Gary, E.; O'Connor, M.; Chakhtoura, M.; Tardif, V.; Kumova, O.K.; Malherbe, D.C.; Sutton, W.F.; Haigwood, N.L.; Kutzler, M.A.; Haddad, E.K. Adenosine deaminase-1 enhances germinal center formation and functional antibody responses to HIV-1 Envelope DNA and protein vaccines. Vaccine 2020, 38, 3821-3831. [CrossRef]

169. Robinson, C.; Baehr, C.; Schmiel, S.E.; Accetturo, C.; Mueller, D.L.; Pravetoni, M. Alum adjuvant is more effective than MF59 at prompting early germinal center formation in response to peptide-protein conjugates and enhancing efficacy of a vaccine against opioid use disorders. Hum. Vaccin. Immunother. 2019, 15, 909-917. [CrossRef]

170. Hutchison, S.; Benson, R.A.; Gibson, V.B.; Pollock, A.H.; Garside, P.; Brewer, J.M. Antigen depot is not required for alum adjuvanticity. FASEB J. 2012, 26, 1272-1279. [CrossRef]

171. Aimanianda, V.; Haensler, J.; Lacroix-Desmazes, S.; Kaveri, S.V.; Bayry, J. Novel cellular and molecular mechanisms of induction of immune responses by aluminum adjuvants. Trends Pharmacol. Sci. 2009, 30, 287-295. [CrossRef]

172. Pulendran, B.; Arunachalam, P.S.; O'Hagan, D.T. Emerging concepts in the science of vaccine adjuvants. Nat. Rev. Drug Discov. 2021, 20, 454-475. [CrossRef]

173. Shi, S.; Zhu, H.; Xia, X.; Liang, Z.; Ma, X.; Sun, B. Vaccine adjuvants: Understanding the structure and mechanism of adjuvanticity. Vaccine 2019, 37, 3167-3178. [CrossRef] [PubMed]

174. De Donato, S.; Granoff, D.; Minutello, M.; Lecchi, G.; Faccini, M.; Agnello, M.; Senatore, F.; Verweij, P.; Fritzell, B.; Podda, A. Safety and immunogenicity of MF59-adjuvanted influenza vaccine in the elderly. Vaccine 1999, 17, 3094-3101. [CrossRef]

175. Calabro, S.; Tortoli, M.; Baudner, B.C.; Pacitto, A.; Cortese, M.; O’Hagan, D.T.; De Gregorio, E.; Seubert, A.; Wack, A. Vaccine adjuvants alum and MF59 induce rapid recruitment of neutrophils and monocytes that participate in antigen transport to draining lymph nodes. Vaccine 2011, 29, 1812-1823. [CrossRef] [PubMed]

176. O'Hagan, D.T. MF59 is a safe and potent vaccine adjuvant that enhances protection against influenza virus infection. Expert Rev. Vaccines 2007, 6, 699-710. [CrossRef] [PubMed]

177. Moris, P.; van der Most, R.; Leroux-Roels, I.; Clement, F.; Dramé, M.; Hanon, E.; Leroux-Roels, G.G.; Van Mechelen, M. H5N1 Influenza Vaccine Formulated with AS03A Induces Strong Cross-Reactive and Polyfunctional CD4 T-Cell Responses. J. Clin. Immunol. 2011, 31, 443-454. [CrossRef]

178. Sparwasser, T.; Vabulas, R.M.; Villmow, B.; Lipford, G.B.; Wagner, H. Bacterial CpG-DNA activates dendritic cells in vivo: T helper cell-independent cytotoxic T cell responses to soluble proteins. Eur. J. Immunol. 2000, 30, 3591-3597. [CrossRef]

179. Klinman, D.M. Therapeutic Applications of CpG-Containing Oligodeoxynucleotides. Antisense Nucleic Acid Drug Dev. 1998, 8 , 181-184. [CrossRef]

180. Pichyangkul, S.; Kum-Arb, U.; Yongvanitchit, K.; Limsalakpetch, A.; Gettayacamin, M.; Lanar, D.E.; Ware, L.A.; Stewart, V.A.; Heppner, D.G.; Mettens, P.; et al. Preclinical evaluation of the safety and immunogenicity of a vaccine consisting of Plasmodium falciparum liver-stage antigen 1 with adjuvant AS01B administered alone or concurrently with the RTS,S/AS01B vaccine in rhesus primates. Infect. Immun. 2008, 76, 229-238. [CrossRef]

181. Vandepapelière, P.; Horsmans, Y.; Moris, P.; Van Mechelen, M.; Janssens, M.; Koutsoukos, M.; Van Belle, P.; Clement, F.; Hanon, E.; Wettendorff, M.; et al. Vaccine Adjuvant Systems containing monophosphoryl lipid A and QS21 induce strong and persistent humoral and $\mathrm{T}$ cell responses against hepatitis B surface antigen in healthy adult volunteers. Vaccine 2008, 26, 1375-1386. [CrossRef] 
182. Bok, S.Y.; Jin, I.S.; Hong, N.; Won, K.S.; Woo, C.Y.; Cheol, K.M.; Seong, L.H.; Tak, J.H.; Hwan, Y.S.; La, C.M.; et al. Crucial Roles of Interleukin-7 in the Development of T Follicular Helper Cells and in the Induction of Humoral Immunity. J. Virol. 2014, 88, 8998-9009. [CrossRef]

183. Li, Y.; Zhao, L.; Sui, B.; Luo, Z.; Zhang, Y.; Wang, Y. Recombinant Rabies Virus Overexpressing OX40-Ligand Enhances Humoral Immune Responses by Increasing T Follicular Helper Cells and Germinal Center B Cells. Vaccines 2020, 8, 144. [CrossRef]

184. Sulczewski, F.B.; Martino, L.A.; Almeida, B.d.S.; Zaneti, A.B.; Ferreira, N.S.; Amorim, K.N.d.S.; Yamamoto, M.M.; Apostolico, J.d.S.; Rosa, D.S.; Boscardin, S.B. Conventional type 1 dendritic cells induce TH1, TH1-like follicular helper T cells and regulatory T cells after antigen boost via DEC205 receptor. Eur. J. Immunol. 2020, 50, 1895-1911. [CrossRef]

185. Godot, V.; Tcherakian, C.; Gil, L.; Cervera-Marzal, I.; Li, G.; Cheng, L.; Ortonne, N.; Lelièvre, J.-D.; Pantaleo, G.; Fenwick, C.; et al TLR-9 agonist and CD40-targeting vaccination induces HIV-1 envelope-specific B cells with a diversified immunoglobulin repertoire in humanized mice. PLoS Pathog. 2020, 16, e1009025. [CrossRef]

186. Andersen, T.K.; Huszthy, P.C.; Gopalakrishnan, R.P.; Jacobsen, J.T.; Fauskanger, M.; Tveita, A.A.; Grødeland, G.; Bogen, B. Enhanced germinal center reaction by targeting vaccine antigen to major histocompatibility complex class II molecules. NPJ Vaccines 2019, 4, 9. [CrossRef] [PubMed]

187. Thompson, E.A.; Ols, S.; Miura, K.; Rausch, K.; Narum, D.L.; Spångberg, M.; Juraska, M.; Wille-Reece, U.; Weiner, A.; Howard, R.F.; et al. TLR-adjuvanted nanoparticle vaccines differentially influence the quality and longevity of responses to malaria antigen Pfs25. JCI Insight 2018, 3, e120692. [CrossRef] [PubMed]

188. Moon, J.J.; Suh, H.; Li, A.V.; Ockenhouse, C.F.; Yadava, A.; Irvine, D.J. Enhancing humoral responses to a malaria antigen with nanoparticle vaccines that expand Tfh cells and promote germinal center induction. Proc. Natl. Acad. Sci. USA 2012, 109, 1080-1085. [CrossRef]

189. Pardi, N.; Hogan, M.J.; Naradikian, M.S.; Parkhouse, K.; Cain, D.W.; Jones, L.; Moody, M.A.; Verkerke, H.P.; Myles, A.; Willis, E.; et al. Nucleoside-modified mRNA vaccines induce potent $\mathrm{T}$ follicular helper and germinal center B cell responses. J. Exp. Med. 2018, 215, 1571-1588. [CrossRef] [PubMed]

190. Lederer, K.; Castaño, D.; Gómez Atria, D.; Oguin 3rd, T.H.; Wang, S.; Manzoni, T.B.; Muramatsu, H.; Hogan, M.J.; Amanat, F.; Cherubin, P.; et al. SARS-CoV-2 mRNA Vaccines Foster Potent Antigen-Specific Germinal Center Responses Associated with Neutralizing Antibody Generation. Immunity 2020, 53, 1281-1295.e5. [CrossRef]

191. Pauthner, M.; Havenar-Daughton, C.; Sok, D.; Nkolola, J.P.; Bastidas, R.; Boopathy, A.V.; Carnathan, D.G.; Chandrashekar, A.; Cirelli, K.M.; Cottrell, C.A.; et al. Elicitation of Robust Tier 2 Neutralizing Antibody Responses in Nonhuman Primates by HIV Envelope Trimer Immunization Using Optimized Approaches. Immunity 2017, 46, 1073-1088.e6. [CrossRef]

192. Cirelli, K.M.; Carnathan, D.G.; Nogal, B.; Martin, J.T.; Rodriguez, O.L.; Upadhyay, A.A.; Enemuo, C.A.; Gebru, E.H.; Choe, Y.; Viviano, F.; et al. Slow Delivery Immunization Enhances HIV Neutralizing Antibody and Germinal Center Responses via Modulation of Immunodominance. Cell 2019, 177, 1153-1171.e28. [CrossRef] [PubMed]

193. Regules, J.A.; Cicatelli, S.B.; Bennett, J.W.; Paolino, K.M.; Twomey, P.S.; Moon, J.E.; Kathcart, A.K.; Hauns, K.D.; Komisar, J.L.; Qabar, A.N.; et al. Fractional Third and Fourth Dose of RTS,S/AS01 Malaria Candidate Vaccine: A Phase 2a Controlled Human Malaria Parasite Infection and Immunogenicity Study. J. Infect. Dis. 2016, 214, 762-771. [CrossRef] [PubMed]

194. Darrah, P.A.; Zeppa, J.J.; Maiello, P.; Hackney, J.A.; Wadsworth, M.H.; Hughes, T.K.; Pokkali, S.; Swanson, P.A.; Grant, N.L.; Rodgers, M.A.; et al. Prevention of tuberculosis in macaques after intravenous BCG immunization. Nature 2020, 577, 95-102 [CrossRef] [PubMed]

195. Nguyen, N.D.N.T.; Olsen, A.W.; Lorenzen, E.; Andersen, P.; Hvid, M.; Follmann, F.; Dietrich, J. Parenteral vaccination protects against transcervical infection with Chlamydia trachomatis and generate tissue-resident $\mathrm{T}$ cells post-challenge. NPJ Vaccines 2020, 5, 7. [CrossRef] [PubMed]

196. Joo, H.M.; He, Y.; Sundararajan, A.; Huan, L.; Sangster, M.Y. Quantitative analysis of influenza virus-specific B cell memory generated by different routes of inactivated virus vaccination. Vaccine 2010, 28, 2186-2194. [CrossRef] [PubMed]

197. Rioux, G.; Mathieu, C.; Russell, A.; Bolduc, M.; Laliberté-Gagné, M.-E.; Savard, P.; Leclerc, D. PapMV nanoparticles improve mucosal immune responses to the trivalent inactivated flu vaccine. J. Nanobiotechnol. 2014, 12, 19. [CrossRef]

198. Counoupas, C.; Ferrell, K.C.; Ashhurst, A.; Bhattacharyya, N.D.; Nagalingam, G.; Stewart, E.L.; Feng, C.G.; Petrovsky, N.; Britton, W.J.; Triccas, J.A. Mucosal delivery of a multistage subunit vaccine promotes development of lung-resident memory $\mathrm{T}$ cells and affords interleukin-17-dependent protection against pulmonary tuberculosis. NPJ Vaccines 2020, 5, 105. [CrossRef]

199. Flórido, M.; Muflihah, H.; Lin, L.C.W.; Xia, Y.; Sierro, F.; Palendira, M.; Feng, C.G.; Bertolino, P.; Stambas, J.; Triccas, J.A.; et al Pulmonary immunization with a recombinant influenza A virus vaccine induces lung-resident CD4+ memory T cells that are associated with protection against tuberculosis. Mucosal Immunol. 2018, 11, 1743-1752. [CrossRef]

200. Tan, H.-X.; Wheatley, A.K.; Esterbauer, R.; Jegaskanda, S.; Glass, J.J.; Masopust, D.; De Rose, R.; Kent, S.J. Induction of vaginalresident HIV-specific CD8 T cells with mucosal prime-boost immunization. Mucosal Immunol. 2018, 11, 994-1007. [CrossRef]

201. Çuburu, N.; Graham, B.S.; Buck, C.B.; Kines, R.C.; Pang, Y.-Y.S.; Day, P.M.; Lowy, D.R.; Schiller, J.T. Intravaginal immunization with HPV vectors induces tissue-resident CD8+ T cell responses. J. Clin. Investig. 2012, 122, 4606-4620. [CrossRef] [PubMed]

202. Cárdeno, A.; Magnusson, M.K.; Quiding-Järbrink, M.; Lundgren, A. Activated T follicular helper-like cells are released into blood after oral vaccination and correlate with vaccine specific mucosal B-cell memory. Sci. Rep. 2018, 8, 2729. [CrossRef] [PubMed]

203. Lambert, P.H.; Laurent, P.E. Intradermal vaccine delivery: Will new delivery systems transform vaccine administration? Vaccine 2008, 26, 3197-3208. [CrossRef] 
204. Knight, F.C.; Gilchuk, P.; Kumar, A.; Becker, K.W.; Sevimli, S.; Jacobson, M.E.; Suryadevara, N.; Wang-Bishop, L.; Boyd, K.L.; Crowe Jr, J.E.; et al. Mucosal Immunization with a pH-Responsive Nanoparticle Vaccine Induces Protective CD8(+) Lung-Resident Memory T Cells. ACS Nano 2019, 13, 10939-10960. [CrossRef]

205. Wang, J.; Li, P.; Yu, Y.; Fu, Y.; Jiang, H.; Lu, M.; Sun, Z.; Jiang, S.; Lu, L.; Wu, M.X. Pulmonary surfactant-biomimetic nanoparticles potentiate heterosubtypic influenza immunity. Science 2020, 367, eaau0810. [CrossRef]

206. Zacharias, Z.R.; Ross, K.A.; Hornick, E.E.; Goodman, J.T.; Narasimhan, B.; Waldschmidt, T.J.; Legge, K.L. Polyanhydride Nanovaccine Induces Robust Pulmonary B and T Cell Immunity and Confers Protection Against Homologous and Heterologous Influenza A Virus Infections. Front. Immunol. 2018, 9, 1953. [CrossRef]

207. Rakhra, K.; Abraham, W.; Wang, C. Exploiting albumin as a mucosal vaccine chaperone for robust generation of lung-resident memory T cells. Sci. Immunol. 2021, 6, eabd8003. [CrossRef] [PubMed]

208. Xia, J.; Kuang, Y.; Liang, J.; Jones, M.; Swain, S.L. Influenza Vaccine-Induced CD4 Effectors Require Antigen Recognition at an Effector Checkpoint to Generate CD4 Lung Memory and Antibody Production. J. Immunol. 2020, 205, 2077-2090. [CrossRef]

209. Lapuente, D.; Storcksdieck genannt Bonsmann, M.; Maaske, A.; Stab, V.; Heinecke, V.; Watzstedt, K.; Heß, R.; Westendorf, A.M.; Bayer, W.; Ehrhardt, C.; et al. IL-1 $\beta$ as mucosal vaccine adjuvant: The specific induction of tissue-resident memory T cells improves the heterosubtypic immunity against influenza A viruses. Mucosal Immunol. 2018, 11, 1265-1278. [CrossRef] [PubMed]

210. Thompson, E.A.; Darrah, P.A.; Foulds, K.E.; Hoffer, E.; Caffrey-Carr, A.; Norenstedt, S.; Perbeck, L.; Seder, R.A.; Kedl, R.M.; Loré, K. Monocytes Acquire the Ability to Prime Tissue-Resident T Cells via IL-10-Mediated TGF- $\beta$ Release. Cell. Rep. 2019, 28, 1127-1135.e4. [CrossRef]

211. Kingstad-Bakke, B.; Toy, R.; Lee, W.; Pradhan, P.; Vogel, G.; Marinaik, C.B.; Larsen, A.; Gates, D.; Luu, T.; Pandey, B.; et al. Polymeric Pathogen-Like Particles-Based Combination Adjuvants Elicit Potent Mucosal T Cell Immunity to Influenza A Virus. Front. Immunol. 2021, 11, 559382. [CrossRef]

212. Calder, P.C. Nutrition and immunity: Lessons for COVID-19. Eur. J. Clin. Nutr. 2021, 75, 1309-1318. [CrossRef]

213. Sudfeld, C.R.; Navar, A.M.; Halsey, N.A. Effectiveness of measles vaccination and vitamin A treatment. Int. J. Epidemiol. 2010, 39 (Suppl. 1), i48-i55. [CrossRef] [PubMed]

214. World Health Organization Measles vaccines: WHO position paper. Wkly. Epidemiol. Rec. 2009, 84, 349-360.

215. Scholz, J.; Kuhrau, J.; Heinrich, F.; Heinz, G.A.; Hutloff, A.; Worm, M.; Heine, G. Vitamin A controls the allergic response through T follicular helper cell as well as plasmablast differentiation. Allergy. Eur. J. Allergy Clin. Immunol. 2021, 76, 1109-1122. [CrossRef]

216. Yang, C.; Yao, H.; Wu, Y.; Sun, G.; Yang, W.; Li, Z.; Shang, L. Status and risks of selenium deficiency in a traditional seleniumdeficient area in Northeast China. Sci. Total Environ. 2021, 762, 144103. [CrossRef] [PubMed]

217. Deng, J.; Chen, Q.; Chen, Z.; Liang, K.; Gao, X.; Wang, X.; Makota, F.V.; Ong, H.S.; Wan, Y.; Luo, K.; et al. The metabolic hormone leptin promotes the function of $\mathrm{T}(\mathrm{FH})$ cells and supports vaccine responses. Nat. Commun. 2021, 12, 3073. [CrossRef] 